\title{
Unity or Uniformity? Domestic Courts and Treaty Interpretation
}

\author{
HELMUT PHILIPP AUST, ALEJANDRO RODILES, AND PETER STAUBACH*
}

\begin{abstract}
The role of domestic courts in the application of international law is one of the most vividly debated issues in contemporary international legal doctrine. However, the methodology of interpretation of international norms used by these courts remains underexplored. In particular, the application of the Vienna rules of treaty interpretation by domestic courts has not been sufficiently assessed so far. Three case studies (from the US Supreme Court, the Mexican Supreme Court, and the European Court of Justice) show the diversity of approaches in this respect. In the light of these case studies, the article explores the inevitable tensions between two opposite, yet equally legitimate, normative expectations: the desirability of a common, predictable methodology versus the need for flexibility in adapting international norms to a plurality of domestic environments.
\end{abstract}

\section{Key words}

domestic courts; treaty interpretation; United States; Mexico; European Union

\section{INTRODUCTION}

International lawyers traditionally harboured a certain degree of scepticism towards the application of international law by domestic courts. It was suspected that their leanings were overly nationalistic, that they broadly construed norms that served their particular country's interest and interpreted restrictively less favourable norms. Moreover, it was noted that national courts tended to yield to the executive branch when it came to international affairs, trying to keep themselves out of a field they perceived as unsuitable for judicial decision-making. 'Avoidance canons' referred either to a bundle of judicial techniques designed to prevent a court's engagement in the pitfalls of international relations (such as the political-question doctrine), or

\footnotetext{
All Humboldt University, Berlin, Faculty of Law [helmut.aust@jura.hu-berlin.de, alejandro.rodiles@jura.huberlin.de, and peter.staubach@jura.hu-berlin.de]. The authors would like to thank Georg Nolte, Thomas Kleinlein, Michael Waibel, Katharina Berner, and Christian Djeffal, as well as the anonymous reviewer, for helpful comments and discussion. Any mistakes are our own. Research for this article was carried out in the framework of the project 'Domestic Courts and the Interpretation of International Law', funded by the Deutsche Forschungsgemeinschaft and conducted in the framework of the European Collaborative Research Project, 'International Law through the National Prism' (Io-ECRP-028).
} 
to general concepts applied to this effect (such as rigid interpretations of standing requirements). ${ }^{\mathrm{I}}$

Meanwhile, it is a well-observed tendency for national courts to increasingly abandon their traditional deference to the executive branch with respect to the determination and interpretation of international law. At the same time, they seem to be more eager to decide questions of international law on the merits: their classic avoidance techniques are less frequently applied. ${ }^{2}$ The explanations offered for the increased eagerness of municipal courts to deal with matters of international law vary. Some allege that national courts try to bolster their institutional position visà-vis the executive, in a time when the advance of globalization threatens to divest them of many fields of activity formerly dealt with at the national level. ${ }^{3}$ Others submit that domestic courts seem to regard themselves more and more as 'agents of the international community' when applying international law. In this context, Georges Scelle's notion of dédoublement fonctionnel ${ }^{4}$ has received attention again. ${ }^{5}$

The position of domestic courts in the international legal process can be compared to that of Goldoni's 'servant of two masters': whereas their legitimacy stems from domestic sources, most often the constitution and laws enacted in accordance with it, some of them also try to accommodate the commands and restrictions international law places upon them. ${ }^{6}$ With their judgments, they have to appeal to both domestic and international audiences. It is not surprising that this situation has led to considerable academic interest. ${ }^{7}$ Curiously, though, this widespread interest focuses mainly on the institutional ramifications of the use of international law by domestic courts - their function and authority as a counterweight to the other branches of government, their relationships with other domestic courts and international bodies of adjudication, their motivations and strategies, and related issues. A cognate question, one of great theoretical as well as practical import, has received

I E. Benvenisti, 'Judicial Misgivings Regarding the Application of International Law: An Analysis of Attitudes of National Courts', (I993) 4 EJIL I59, at I69.

2 E. Benvenisti, 'Reclaiming Democracy: The Strategic Uses of Foreign and International Law by Domestic Courts', (2008) I02 AJIL 24I, at 242.

3 A.-M. Slaughter, 'A Global Community of Courts', (2003) 44 Harvard International Law Journal I9I, at I92; E. Benvenisti and G. W. Downs, 'National Courts, Domestic Democracy, and the Evolution of International Law', (2009) 20 EJIL 59, at 60-I.

4 G. Scelle, Précis de droit des gens: Principes et systématique, Vol. 2 (I934), at Io-I 2.

5 Y. Shany, “Dédoublement fonctionnel" and the Mixed Loyalties of National and International Judges', in F. Fontanelli (ed.), Shaping Rule of Law through dialogue (2010), 28 at 40.

6 As is evident from the widespread use of the technique of 'consistent interpretation': see A. Cassese, 'Modern Constitutions and International Law', (I985) I92 RdC 33I; G. Betlem and A. Nollkaemper, 'Giving Effect to Public International Law and European Community Law before Domestic Courts: A Comparative Analysis of the Practice of Consistent Interpretation', (2003) I4 EJIL 569.

7 See Benvenisti and Downs, supra note 3; F. Francioni, 'International Law as a Common Language for National Courts', (200I) 36 Texas International Law Journal 587; K. Knop, 'Here and There: International Law in Domestic Courts', (2000) 32 New York University Journal of International Law and Politics 50I; K. Parrot-Gilbert, "La jurisprudence interne, "source" de droit international conventionnel? A propos de L'application des conventions portant "loi uniforme”, (2009) I I 3 RGDIP I9; A. Roberts, 'Comparative International Law? The Role of National Courts in Creating and Enforcing International Law', (20I I) 6o ICLQ 57; A. Nollkaemper, National Courts and the International Rule of Law (2OI I); J. d'Aspremont, 'The Systemic Integration of International Law by Domestic Courts: Domestic Judges as Architects of the Consistency of the International Legal Order', in O. K. Fauchald and A. Nollkaemper (eds.), The Practice of International and National Courts and the (De-)Fragmentation of International Law (2012), I4I. 
considerably less attention: how do national courts apply international law? How do they interpret it? ${ }^{8}$

The growing use of international law by domestic courts is usually hailed as a positive trend, providing effective means of enforcement and strengthening the international rule of law. Yet, the growing engagement of national judges in the interpretation of international law may also have an impact on the structure of the international legal system. Several effects of this trend are conceivable. In this article, we assess these potential effects in the light of four recurring themes: first, it needs to be identified whether domestic courts are aware of the existence of a distinct hermeneutical framework when they decide cases pertaining to questions of international law. In other words: do they acknowledge that international law provides for specific rules of interpretation? We will show that despite a general awareness of these distinct methods of interpretation, the practice of domestic courts is characterized by considerable diversity in this regard. This leads, second, to the question whether this diversity of domestic legal methodologies might lead to a further fragmentation of international law. A related concern is, third, that influential courts (whether due to their juridical distinction or the political importance of their country) might rush ahead with a particularly 'progressive' interpretation of an international norm, thus giving rise to a new kind of unilateralism, a form of 'judicial imperialism'. ${ }^{9}$ Finally, these questions refer back to Scelle's dédoublement: courts that feel bound by loyalty to the international community might conceivably be more inclined to reflect on questions of methodology when construing a treaty.

In our analysis, we will proceed in three steps. In the first, we will present the normative framework within which our research question is located, i.e. the normative and conceptual environment where the interpretation of international treaty law by domestic judges takes place. This provides the analytical background against which we can present, in the second step, the case law of three jurisdictions we have selected as case studies: the European Union, Mexico, and the United States. It will become apparent that there is considerable variance in the way in which domestic courts approach the issue of treaty interpretation. In a third step, we will then turn to the four recurrent themes we have just identified. Their discussion will provide the ground for some brief conclusions. In all this, it is not our intention to commend a set of correct rules of interpretation and then provide cherry-picked judgments in support of our approach; in fact, we are less concerned with particular rules and their merits than with the general importance of hermeneutical awareness in a decentralized and diverging system of social order. As the three case studies will show, the role of courts within their specific social and political contexts, i.e. their institutional environment, has also to be considered as a 'broader dimension'to of this hermeneutical awareness. Attention will thus be paid to how the self-perception

8 One of the most comprehensive studies on this issue is still C. H. Schreuer, 'The Interpretation of Treaties by Domestic Courts', (I97I) 45 BYIL 255.

9 For the position that influential courts should go ahead see Roberts, supra note 7.

Io See further M. Poiares Maduro, 'Courts and Pluralism: Essay on a Theory of Judicial Adjudication in the Context of Legal and Constitutional Pluralism', in J. L. Dunoff and J. P. Trachtman (eds.), Ruling the World? Constitutionalism, International Law, and Global Governance (2009), 356 at 359. 
of domestic courts within their national, regional, and international realms affects their interpretative practices.

\section{LEGAL PLURALISM AND THE RULE OF LAW: WHY INTERPRETATION MATTERS}

\section{I. The indeterminacy controversy}

It is almost a thought-terminating cliché today that rules of interpretation have little if any effect on the outcome of a particular case. As Hersch Lauterpach wrote in I949, 'as a rule they are not the determining cause of judicial decision, but the form in which the judge cloaks a result arrived at by other means'. ${ }^{\text {II }}$ A more fundamental critique has been that the indeterminacy of language makes it impossible to base the decision of a concrete case on the abstract words of a legal rule. ${ }^{\text {I2 }}$ From this alleged indeterminacy it was inferred that interpretation is just the suppression of an inevitable ambiguity, with legal hermeneutics being 'a set of hegemonic moves that make particular arguments or preferences seem something other than particular because they seem, for example "coherent" with the "principles" of the legal system'. ${ }^{\text {I3 }}$ In a weaker form, these doubts on the usefulness of methodology are reflected in the truism that interpretation is 'an art, not an exact science'. ${ }^{\text {4 }}$

While these critical insights stress important limits to the rules of interpretation, it still appears that judicial and societal practice largely upholds the assumption that there is some determinacy in law and that it is ultimately possible to arrive at a common understanding of a norm. When courts decide cases and thereby settle disputes for the parties, they rely on the fiction that there are legal reasons which justify a certain result. Courts can be more or less persuasive in the giving of reasons, but it is important that they do so, in order for the participants in the legal process to understand why a particular decision has been reached, and not a different one. ${ }^{15}$ The social practice of recognizing this process as something useful to society gives the fiction its practical relevance. ${ }^{16}$ The rules of interpretation help to narrow the scope of admissible arguments. ${ }^{17}$ Even Koskenniemi admits that an important task of international lawyers is to determine which arguments can plausibly be advanced in the legal discourse and which are unsusceptible to acceptance by the legal

I I H. Lauterpacht, 'Restrictive Interpretation and the Principle of Effectiveness in the Interpretation of Treaties', (I949) 26 BYIL 48 , at 53.

I 2 On the debate and its flaws see L. Solum, 'On the Indeterminacy Crisis: Critiquing Critical Dogma', (I987) 54 University of Chicago Law Review 462.

I3 M. Koskenniemi, From Apology to Utopia (2005 reissue), 597.

I4 Yearbook of the International Law Commission (I966, Vol. 2), 2 I 8, para 4. On this saying, see also J.-M. Sorel and V. Boré Eveno, 'Article 3I', in O. Corten and P. Klein (eds.), The Vienna Convention on the Law of Treaties (20II), Art. 3I, para. I 2.

I5 On the importance of giving reasons, see B. Kingsbury, 'International Law as Inter-Public Law', in H. S. Richardson and M. S. Williams, Moral Universalism and Pluralism (2009), I78, at I80.

I6 On meaning as a social construct in the interpretation of international law, see A. Bianchi, 'Textual Interpretation and (International) Law Reading: The Myth of (In)Determinacy and the Genealogy of Meaning', in P. H. F. Bekker, R. Dolzer, and M. Waibel (eds.), Making Transnational Law Work in the Global Economy: Essays in Honour of Detlev Vagts (2010), 34.

I 7 Cf. O. M. Fiss, 'Objectivity and Interpretation', (I 982) 34 Stanford Law Review 739, at 744. 
community. ${ }^{\text {I } 8}$ For the decentralized international legal system, the question is what importance needs to be ascribed to the international rules of interpretation by domestic courts. Behind this question lies the even bigger one of how this legal system shall be understood: is it premised on an all-encompassing uniformity of interpretation, i.e. the goal that all relevant actors are supposed to interpret international obligations in exactly the same way? Or is it sufficient that the international legal system is held together by some common rules which ensure systemic unity at a general level, but allow for deviation and pluralism in specific situations?

\subsection{Rules of interpretation and the rule of law}

In every legal system, rules of interpretation play a fundamental role in the administration of justice, as they govern the primary activity of the judge and the construction of the law, and ultimately help determine the result. ${ }^{19}$ However, questions of methodology rarely attract much public attention, ${ }^{20}$ since it is the outcome of a case that is ultimately assessed, not the way the judges reached it. Nevertheless, these so-called 'secondary norms' ${ }^{\text {'II }}$ (as opposed to the primary norms to which they are applied) serve a number of important purposes.

First, they guarantee the autonomy of the legal system, whose claim to an independent existence depends on the fact that it works in a different way than other (sub)systems of society (such as the political or the economic spheres); decides under a different procedure; and, most importantly, is confined to a limited number of ways in which arguments may be advanced, ways which are predefined and originate from within the system itself. Only under these conditions can the idea be maintained that the interpretation of law by a judge is guided by objective, neutral principles, ideally leading to a convincing result that is able to pacify the controversy. Second, rules of interpretation can promote stability and reliability in a legal system, make the courts' actions more predictable, and thereby strengthen the confidence of all relevant social actors that their legitimate expectations will not be disappointed. Thus, they have a direct bearing on the authority and respect that a system of law and its representatives - enjoy. Finally, secondary norms, such as the rules of interpretation, protect the unity and integrity of the legal system: they resolve conflicts between different primary norms, provide methods to fill gaps in the legal fabric, and limit the exercise of judicial power, by setting limits to interpretative discretion. Although the work of the judge may have an inherent tendency towards arbitrariness, at least the possibility of excess is limited by a duty to justify the result in terms of methodology. ${ }^{22}$

I8 Koskenniemi, supra note I3, at II.

I9 A. Barak, The Judge in a Democracy (2006), I33.

20 An exception to this observation is the debate over the proper method of interpreting the US Constitution, leading to quarrels in the federal judiciary between 'originalists' and proponents of the idea of a 'living' constitution.

2 I H. L. A. Hart, The Concept of Law (I994), at 94-9; on secondary rules in international law see further Nollkaemper, supra note 7 , at 224-6.

22 In a sense, rules of interpretation help prevent the excesses of judicial activism by recalling that case law too has to be able to speak on behalf of the whole society and to society as a whole, cf. Kingsbury, supra note I5. 
These general observations regarding the importance of secondary norms in shaping and structuring legal systems are of particular relevance in a non-hierarchical system like international law where the way to achieve autonomy, integrity, and coherence seems much longer and more tedious. With respect to the judicial application of international law, one difference between international and domestic tribunals deserves mentioning: whereas international judges, though of various national origins, usually belong to the proverbial 'invisible college of international lawyers', ${ }^{23}$ national judges from different jurisdictions share far fewer similarities in mindset, education, and their perception of the judicial role.

It is therefore not surprising that international law today can look back on a rich, distinct doctrinal history of treaty interpretation. A direct line can be drawn from the Graeco-Roman approaches to legal arguments, the constitutiones legitimae, to Gentili, Grotius, Vattel, and Pufendorf, all of whom devoted significant efforts to the development of rules on treaty interpretation, recognizing the importance of having a universal methodology independent of individual states' will. ${ }^{24}$ The rules formulated by these founding fathers of international law, a mixture of abstract logical maxims, concrete legal principles, and natural-law concepts like 'good faith', essentially remained the canon of interpretation that was applied by courts and restated in textbooks until the middle of the twentieth century. ${ }^{25}$

Building on these previous achievements, the UN's International Law Commission (ILC) adopted in I 966 their Draft Articles on the Law of Treaties, most of which found their way into the Vienna Convention on the Law of Treaties (VCLT) of I 969. The rules of interpretation, contained in Articles 3 I-3 VCLT, have since then been critically discussed and are by now widely accepted as reflecting customary international law. ${ }^{26}$ They give preference to objective over subjective interpretation, with Article 3 I making a treaty's text the main source of its construction. ${ }^{27}$ This textualism, somewhat mitigated by the fact that Article 3I permits resort to context and subsequent practice, has been the primary cause of criticism levelled against the Vienna rules; proponents of a subjective method, focusing on the parties' intent, labelled it 'the grossest exercise of arbitrary formalism'. ${ }^{28}$ In this question, as well as in the restriction Article 32 puts on the use of travaux préparatoires, the VCLT rules are at variance with some long-standing domestic traditions of treaty interpretation;

23 O. Schachter, 'The Invisible College of International Lawyers', (1977) 72 Northwestern University Law Review 217.

24 For this history see D. J. Bederman, Classical Canons: Rhetoric, Classicism and Treaty Interpretation (200I).

25 Lauterpacht, supra note i I, at 50.

26 See Case Concerning Avena and Other Mexican Nationals (Mexico v. United States of America), Judgment of 3I March 2004, [2004] ICJ Rep. I2, at 48, para. 83; Case Concerning Sovereignty over Pulau Ligitan and Pulau Sipadan (Indonesia v. Malaysia), Judgment of I7 December 2002, [2002] ICJ Rep. 625, at 645, para. 37, with further references; Case Concerning Kasikili/Sedudu Island (Botswana v. Namibia), Judgment of I 3 December I999, [1999] ICJ. Rep. I045, at I059, para. I8; Land, Island and Maritime Frontier Dispute (El Salvador v. Honduras; Nicaragua Intervening), Judgment of I September I992, [I992] ICJ Rep. 35I, at 586, para. 380; see also Art. 2(2)(b) of the Resolution of the Institut de droit international on 'L'interprétation des traités', (I956) Annuaire IDI 359.

27 According to some, however, the general rule of interpretation embodies a compromise between objective and subjective schools of treaty interpretation; see R. Gardiner, Treaty Interpretation (2008), at 8.

28 M. S. McDougal, H. Laswell, and J. Miller, The Interpretation of Agreement and World Public Order (I994), xvii. 
the practice of courts in the United States is the best-known example. ${ }^{29}$ Nevertheless, just as any norm, the VCLT rules are subject to interpretation; and arguably the holistic approach of Article 3I includes all major schools of interpretation, namely textualism ('ordinary meaning'), teleology ('object and purpose') and, less explicitly, intentionalism ('good faith').

As argued above, rules of interpretation are indispensable for any advanced legal order. When it comes to national courts, the question is: is it desirable that they all apply the same rules of interpretation when construing international treaties? Or could it be a productive form of cross-fertilization to introduce different national methodologies to the international legal process, thereby eventually enriching the international practice? This could be of particular value as also international courts of general jurisdiction, most notably the ICJ, have not yet framed a consistent scheme of interpretation. ${ }^{30}$

\subsection{The challenge of pluralism}

From the perspective of the international legal system, it appears as if there is an expectation of the highest possible degree of coherence in the practice of domestic courts. With respect to many international agreements, it is indeed the main purpose to ensure uniformity of rules and behaviour among the parties. To reach this goal, it does not suffice to adopt a single authoritative text - uniform application of the agreed rules is required. This is quite undisputed in the case of treaties with a rather technical content, such as the Warsaw or the Montreal Conventions - evidently, it is not feasible to have different interpretations of the rules of civil aviation applied in every member state.

Quite differently, regional human rights instruments may only set forth minimum standards which are subsidiary to the protection of fundamental rights in national legal systems. Here, consistency in interpretation can only be a legitimate goal in so far as the minimum standard must be met by all state parties to the respective regime. Arguably, it is not illegitimate to devise new interpreative methods which help to go beyond what is required by the treaty if this does not lead to deficits in rights protection for other involved actors. ${ }^{3 \mathrm{I}}$

Yet, the challenge described here goes clearly beyond specific problems of certain treaty regimes, and concerns the broader argument that strict consistency and coherence of the whole system of international law may not be desirable in the first place. It could be argued that such uniformity might stand in the way of legal development and that it might help to protect conservative structures upon which self-interested states have agreed. In times in which some authors describe our international - or rather global - legal system in pluralist terms, it might be reasonable to

29 See, e.g., D. Vagts, ‘Treaty Interpretation and the New American Way of Law Reading', (I993) 4 EJIL 472, at $49 \mathrm{I}$.

30 Cf. E. S. Yambrusic, Treaty Interpretation (I987), I44. See also S. Torres Bernárdez, 'Interpretation of Treaties by the International Court of Justice Following the Adoption of the I969 Vienna Convention on the Law of Treaties', in G. Hafner et al. (eds.), Liber Amicorum Professor Ignaz Seidl-Hohenveldern in Honour of His 8oth Birthday (I998), 72I, at 747.

3 I See F. G. Jacobs, 'Introduction', in F. G. Jacobs and S. Roberts (eds.), The Effect of Treaties in Domestic Law (I 987 ), xxiii, at xxxi, note 25 . 
assume that different legal cultures and forms of education will necessarily impact on the way courts reason on questions of international law. Should we not rather, in the light of these considerations, recognize domestic courts as actors who translate requirements from international law into domestic terminology, ${ }^{32}$ and thus help to increase the legitimacy of international law? Already in I964, Richard Falk argued that

the role of domestic courts relates to the increasing participation in world affairs of nations with diverse normative traditions. It is generally acknowledged that international law - as a dynamic system - suffers from its historical attachment to European culture. If law is to bring increasing stability to international relations, then it must progressively liberate itself from its somewhat provincial past. This requires a respect for diversity more than an agreement upon universal standards. ${ }^{33}$

However, there is an inherent tension in this remark. Falk pleads for diversity, but with stability in mind. These dialectics point towards the reason why we stress the importance of relative unity in the domain of method and, more broadly speaking, in the realm of secondary rules. We maintain that challenges to an overly demanding conception of uniformity can be reconciled with coherence on the level of secondary rules. The secondary rules are what defines a legal system. They help to build and to maintain its integrity. ${ }^{34}$ For this integrity to exist, at least a certain level of predictability is necessary, and this is what secondary rules are about. At the same time, this predictability enables agreement within diversity. By contributing to a more objective articulation of national courts' normative preferences regarding international law questions, the recognized criteria for interpretation facilitate dialogue and, ultimately, the possibilities of agreement among them. ${ }^{35}$ The rules of interpretation are an important part of such a common frame of reference.

This is recognized by some adherents of (constitutional) pluralism. Neil MacCormick, for instance, argued for a pluralism of legal systems 'ordered under international law'. ${ }^{6}$ When describing the 'pluralist constellation in global governance', Daniel Halberstam emphasizes the importance of 'general rules governing the creation, modification and interpretation of treaties' ${ }^{37}$ As can be expected given the varying forms of pluralist approaches to international and transnational law, ${ }^{38}$ not all pluralists would agree. The position of Halberstam may show, however, that the argument for a certain level of coherence in the field of secondary rules and, more particularly, the rules governing the interpretation of international law need not be associated with hierarchical, top-down models of global governance.

\footnotetext{
See Knop, supra note 7.

R. Falk, The Role of Domestic Courts in the International Legal Order (I964), at 66.

See Hart, supra note $2 \mathrm{I}$.

Cf. Poiares Maduro, supra note io, at 359-6I.

6 N. MacCormick, 'Risking Constitutional Collision in Europe?', (I998) I8 Oxford Journal of Legal Studies 5I 7, at 527 et seq.; see further the conversation between Weiler and Halberstam in J. H. H. Weiler, 'Dialogical Epiloque', in G. de Búrca and J. H. H. Weiler (eds.), The Worlds of European Constitutionalism(20I 2), 262 at 288.

37 Daniel Halberstam, 'Local, Global and Plural Constitutionalism: Europe Meets the World', in de Búrca and Weiler, supra note 36 , I I3, at I67.

38 See N. Krisch, 'The Case for Pluralism in Postnational Law', in de Búrca and Weiler, supra note 36, 203 at 220.
} 
Articles 3 I-3 VLCT may just serve the purpose of contributing to a common foundation for judicial dialogue in a pluralist environment. In this regard, what is frequently viewed as a deficit of these rules may turn into a particular strength: the rules of interpretation themselves are open-textured. Hence, they leave room for assimilation by national courts, which is often required by domestic audiences, while, at the same time, they provide for important clarifications, which facilitate the connection with the external audiences, and the co-ordination amongst them. This is of particular importance in a world where the internal/external divide is ever more questioned. The rules of interpretation contribute to these connections and reconnections by specifying the sources that may be looked at to discern the shared intent of the parties, the ultimate goal of treaty interpretation. The outstanding importance of the treaty's text as a whole is stressed, but rigid literalism is discouraged by the reference to object and purpose. In enumerating the sources which constitute the 'context', the Vienna Convention alerts the interpreter to an important issue: the different forms in which the parties can at any time express their agreement on a particular (authoritative) interpretation. Especially the most informal mode, provided for in Article 3 I (3)(b) ('subsequent practice... which establishes the agreement of the parties'), can prove to be challenging for domestic judges, although it is a common usage in domestic contract law to look at the parties' later conduct to divine the meaning of an earlier agreement. ${ }^{39}$

Altogether, the rules of interpretation should not be conceived as a precise guideline that judges can follow blindly to reach a cogent result. ${ }^{40}$ They tell the judges what they should look at, but leave it to their discretion which glasses to put on. Moreover, they do not contain any of the classic default rules such as restrictive interpretation (in ambiguous cases, limitations on a state's sovereignty cannot be presumed) or effective interpretation (a norm must be construed to have the greatest possible effect towards its aim), although the latter principle can be read as implied in the phrase 'object and purpose'. The Vienna rules do not put to rest all doubts and uncertainties, nor do they reveal the true meaning; and one should not be tempted by the alleged textualism of Article 3 I to 'make a fortress out of the dictionary'. ${ }^{\text {I }}$ An international treaty, more than any other legal instrument, cannot be understood through mechanical adherence to a doctrine, nor through thoughtless processing of a hierarchical scheme.

In this context, it should also be noted that it can be very much in the self-interest of domestic courts to apply the international rules of interpretation. Adopting an international-law orientated methodology signals the aspiration of the domestic court to apply international law faithfully. Recourse to the international rules of interpretation will not guarantee a certain outcome of the case. But the application

39 A. Glashausser, 'What We Must Never Forget When It Is a Treaty We Are Expounding', (2005) 73 University of Cincinnati Law Review I 243, at I 335. On subsequent practice in international law, see the contributions in G. Nolte (ed.), Treaties and Subsequent Practice (2013).

40 Gardiner, supra note 27, 7.

4I In the words of Judge Learned Hand, who famously observed in Cabell v. Markham,I48 F.2d 737, 739 (I942): '[I]t is one of the surest indexes of a mature and developed jurisprudence not to make a fortress out of the dictionary'; but see for a different view A. Orakhelashvili, The Interpretation of Acts and Rules in Public International Law (2008), 309. 
of domestic canons of statutory construction to an international agreement may potentially caution against the outcome of the case. Other actors, be they involved parties in the case or other states which consider themselves to be injured by a misapplication of international law, will have an easier task of arguing against the outcome of a given case if its result has not been justified in terms of the internationally accepted interpretative standards.

It is perfectly conceivable that individual courts may ignore foreign interpretations of a norm of international law, or come up with interpretations that are legally untenable. But these decisions are likely to fall into oblivion, at least for the external audience; and it cannot be inferred from transgressions that the general rule is invalid. The legal value of a precedent is almost universally determined by its replicability; and we sustain that decisions based on the Vienna rules may have a comparative advantage in this respect.

\section{The PRACTICE OF DOMESTIC COURTS: A COHERENT PiCTURE?}

With these general observations in mind, it is now time to turn to the practice of domestic courts. A recent comparative study on the role of domestic courts in treaty enforcement has come to the conclusion that among the examined legal systems 'substantial similarities exist on the influence of the VCLT almost irrespective of tradition and member-state status' ${ }^{42}$ A look at the country reports assembled in this work casts a shadow of doubt over these generalizing conclusions. The country reports on Canada, Israel, the Netherlands, Poland, and South Africa show considerable diversity with respect to the application of the Vienna rules. ${ }^{43}$

Given that five among the eleven jurisdictions examined in the comparative study allow for further doubts over the impact of the international rules of interpretation on the practice of domestic courts, it is an open question whether the conclusion presented at the outset of this section can hold water. ${ }^{44}$ This is more so as the other six country reports contained in the book do not precisely portray the respective jurisdictions as faithful followers of the Vienna Convention approach. ${ }^{45}$

This state of affairs requires further examination which must eventually be carried out in a broad and empirical manner. We aspire to highlight certain problematic aspects of the recent practice of domestic courts which will allow us to discuss more thoroughly what is at stake when domestic courts decide whether or not to use the international rules of interpretation, or when they do so in a rather peculiar manner.

In order to demonstrate the great variation between domestic courts' interpretative approaches to international law, we will present three case studies, i.e.

42 M. P. van Alstine, 'The Role of Domestic Courts in Treaty Enforcement: Summary and Conclusion', in D. Sloss (ed.), The Role of Domestic Courts in Treaty Enforcement (2009), 555 at 588-9.

43 See G. van Ert, 'Canada', in Sloss, supra note 42, I66 at I8I-2; D. Kretzmer, 'Israel', in ibid., 273 at 298 ; A. Nollkaemper, 'The Netherlands', in ibid., 326 at 362; L. Garlicki, M. Masternak-Kubiak, and K. Wójtowicz, 'Poland', in ibid., 370 at 389; J. Dugard, 'South Africa', in ibid., 448 at 464.

44 See also Nollkaemper, supra note 7, at 2 I9: 'there is ample practice whereby domestic courts apply principles of domestic (statutory) interpretation, apparently unguided by international principles of interpretation'.

45 These are Australia, Germany, India, Russia, the United States, and the United Kingdom; see Sloss, supra note 42. 
the case law of the United States Supreme Court, the approaches to treaty interpretation by the Supreme Court of Mexico, and the development of the case law of the European Court of Justice on questions of international law. Instead of pursuing a comprehensive survey of representative jurisdictions, the guiding principle of our selection of jurisdictions as well as of the particular cases was to assess how courts in different cultural and political settings develop idiosyncratic approaches to treaty interpretation.

\section{I. Treaty interpretation in the US Supreme Court}

For comparative as well as international lawyers, the case law of the US Supreme Court is certainly among the most intriguing fields of study. Indeed, this fascination is owed in part to America's political and cultural dominance, and to its self-perception as a role model for various countries in transition from authoritarianism to democracy. However, the deeper source of the court's attractiveness seems to lie in its heritage of two centuries, a time during which the court consistently developed and refined its jurisprudence, without having much regard for the legal upheavals simultaneously taking place in other nations.

\section{I.I. Liberal interpretation and allegiance to the law of nations}

Much has been written on the US Supreme Court's methodology with respect to treaty interpretation. ${ }^{46}$ However, most of the literature addresses the subject from a US perspective, and the court's basic assumptions are rarely questioned. An outstanding feature of the American rules ('canons' in US parlance) of treaty interpretation is that they reflect the development of the American attitude towards international law and international relations over the past two centuries. ${ }^{47}$ As the US Constitution, while making properly ratified treaties part of the 'supreme law of the land', ${ }^{48}$ is silent on the means of their interpretation, courts were to follow their own legal intuition (and certainly their idea of the United States' place in the world) to develop a proper methodology. The canons thus designed at times resemble philosophical principles rather than actual rules of decision. Most notably the canon of 'good faith' and its corollary, 'liberal interpretation', dominated US treaty interpretation from the late nineteenth until the middle of the twentieth century, reflecting an internationalist attitude reminiscent of the writings of Grotius and Vattel. ${ }^{49}$ The goal of

46 See., e.g., D. Bederman, 'Revivalist Canons and Treaty Interpretation', (I994) 4I UCLA Law Review 953; C. Bradley, 'Chevron Deference and International Relations', (2000) 86 Virginia Law Review 649; L. Fisler Damrosch, 'Interpreting US Treaties in the Light of Human Rights Values', (2002) 46 New York Law School Law Review 43; Glashausser, supra note 39; D. H. Moore, 'Do US Courts Discriminate against Treaties?', (2010) I 10 Columbia Law Review 2228.

47 The general development of the American attitude towards international law has been thoroughly scrutinized in several studies: see, e.g., D. Moynihan, On the Law of Nations (I990), focusing on the politico-legal environment in which the process took place; for a survey of the US Supreme Court's case law see D. Sloss, M. Ramsey, and W. Dodge (eds.), International Law in the US Supreme Court (20I I).

48 See the Supremacy Clause, Article VI, cl. 2 US Constitution: 'and all Treaties made, or which shall be made, under the Authority of the United States, shall be the supreme Law of the Land'.

49 H. Grotius, 'On Interpretation', De Jure Belli ac Pacis, Book II, Ch. XVI; E. de Vattel, Le droit des gens, Tome I, Chapter XVIII; a restatement of the traditional doctrines was provided by W. Hall, Treatise on International Law, 4 th edn. (I895), §§ II I-I3. 
this expansive approach was to safeguard against inadvertent breaches of treaties by judges whose understandings of treaty terms might be inconsistent with the expectations of other parties. ${ }^{\circ}$ As Justice Stephen Field wrote in an I89o decision:

As they [the treaties] are contracts between independent nations, in their construction words are to be taken in their ordinary meaning, as understood in the public law of nations, and not in any artificial sense impressed upon them by local law, unless such restricted sense is clearly intended.... Where a treaty admits of two constructions, one restrictive of rights that may be claimed under it and the other favourable to them, the latter is to be preferred..$^{\text {I }}$

Yet the precept of 'good faith and liberal interpretation' with respect to the construction of treaty terms was but one part of a wider jurisprudential framework the US Supreme Court had been developing ever since the Chief Justiceship of John Marshall, in order to ensure the United States' compliance with international law. A famous example of this is the so-called 'Charming Betsy rule', an early instance of a judicial application of the concept of 'consistent interpretation', which refers to an interpretation of domestic law in conformity with a state's international obligations..$^{2}$ In Murray v. The Charming Betsy, Marshall boldly asserted that an act of Congress 'ought never be construed to violate the law of nations if any other possible construction remains'.53 It is probably fair to attribute the court's attitude in The Charming Betsy as much to the idealistic visions of the framers about what 'a decent respect to the opinions of mankind' demanded, as to rather pragmatic considerations of a young nation in a precarious strategic situation, trying to avoid further frictions with foreign powers. Nevertheless, the generally positive attitude of the US Supreme Court towards the domestic application of international law persisted for more than a century.

\section{I.2. Deference to executive discretion}

Since the middle of the twentieth century the internationalist approach silently fell into desuetude. ${ }^{54}$ In particular during the Chief Justiceship of William H. Rehnquist (I986-2005), the Supreme Court was not so much interested in having recourse to internationally accepted sources and methods of treaty interpretation. Instead, the court preferred to look at the domestic executive branch for interpretative guidance, as well as at the preratification debates in the Senate, just as if a treaty was merely a domestic statute. A significant manifestation of this attitude occurred in

50 See The Amiable Isabella, I9 US I, 68 (I82 I), where Justice Story stated that a treaty had to be interpreted in 'the most scrupulous good faith' in order to protect the government from the 'disgrace' caused by a possible violation of its international obligations.

5I Geofroy v. Riggs, I33 US 258, 27I (I890). The latter part of this quotation could be read also as an early formulation of the so-called pro persona principle, today so much in vogue in several Latin American courts, including Mexican tribunals. See infra section 3.2.3.

52 On consistent interpretation see Nollkaemper, supra note 7, Chapter VII.

53 Murray v. The Charming Betsy, 6 US 64, I 8 (I804).

54 Cf. M. van Alstine, 'The Death of Good Faith in Treaty Jurisprudence and a Call for Resurrection', (2005) 93 Georgetown Law Journal I 885, at I987: 'Unfortunately, good faith has died. With no ceremony and outside the scrutiny of scholars, it was silently interred by the Supreme Court early in the last century'. 
the I992 decision USv. Alvarez-Machain, 55 in which the court had to construe a 1978 extradition treaty with Mexico.

In this case, the court held that the extraterritorial abduction of a Mexican citizen for the purpose of criminal prosecution in the US did not violate the extradition treaty between the two countries, as no explicit prohibition of such abductions could be found in the terms of the treaty. ${ }^{56}$ The majority of the court did not consider the Mexican interpretation of the treaty, filed in an amicus curiae brief, according to which a prohibition of extraterritorial abductions had to be regarded as a necessary corollary of the extradition agreement. The court relied on the US government's interpretation as the controlling one, stating that any bilateral tension created by the abduction should be resolved through diplomatic means without judicial interference. ${ }^{57}$

Although the canon of interpretative deference to the political branches of government had already been applied occasionally in earlier decisions, since AlvarezMachain it has turned into a cornerstone of US treaty interpretation. However, this canon is supplemented by two other distinct and at times contradictory interpretational precepts: a narrow literalism, as apparent in Alvarez-Machain, and, on the other hand, a tendency to resort to extratextual sources of interpretation in a rather indiscriminate and unprincipled manner, even where no significant textual ambiguity is discernible.

The most striking example of the latter approach was the case of Sale v. Haitian Centers Council, Inc. ${ }^{8}$ In this case the court had to construe the extent of the nonrefoulement obligation under Article 33(I) UN Convention Relating to the Status of Refugees, ${ }^{59}$ providing that '[n]o contracting state shall expel or return ('refouler') a refugee in any manner whatsoever to the frontiers or territories where his life or freedom would be threatened on account of his race, religion, ... '. The question was whether this prohibition applied to the practice of the US agencies to intercept Haitian refugees on the high seas and return them to Haiti without having determined their potential status as refugees. In the majority decision, Justice John Paul Stevens managed to turn the all-encompassing language of the treaty, which read 'expel or return ('refouler') ... in any manner whatsoever', into an epitome of vagueness, using domestic statutory provisions to prove that 'expel or return' could only refer to the deportation of aliens already present in a state's territory or at the

55 United States v. Alvarez-Machain, 504 US 655 (I992).

56 This reading of the treaty was pungently criticized in a dissenting opinion authored by Justice Stevens, who observed:

It is true, as the Court notes, that there is no express promise by either party to refrain from forcible abductions in the territory of the other nation. Relying on that omission, the Court, in effect, concludes that the Treaty merely creates an optional method of obtaining jurisdiction over alleged offenders, and that the parties silently reserved the right to resort to self-help whenever they deem force more expeditious than legal process.

To him, 'the manifest scope and object of the treaty [implied] a mutual undertaking to respect the territorial sovereignty of the other contracting party (504 US 655, at 674-5).

57504 US 655, at 669 (at note I6).

58 Sale v. Haitian Centers Council, Inc., 509 US I 55 (I993).

59 I95I Convention Relating to the Status of Refugees, I89 UNTS I 37. 
border, and relied on the French term refouler, inserted by the Convention's drafters to affirm the wide scope of the prohibition, to create further ambiguity:

This suggestion - that 'return' has a legal meaning narrower than its common meaning - is reinforced by the parenthetical reference to 'refouler', a French word that is not an exact synonym for the English word 'return'. Indeed, neither of two respected EnglishFrench dictionaries mentions 'refouler' as one of many possible French translations. ${ }^{60}$

Then, the court felt free to look beyond the text and affirm its result by a cursory review of the travaux préparatoires, relying mainly on an isolated statement by a representative from the Netherlands. As often in the Rehnquist Court's treaty decisions, this analysis was carried out 'without any real appreciation of the mechanics of international conference diplomacy, and how those dynamics differ substantially from legislative patterns'. ${ }^{6}$ I Defying the clear language and purpose of the Convention, the Court concluded that a state is entitled to send back refuge seekers, provided it manages to interdict them before they arrive at its border. This was convincingly criticized by Justice Harry Blackmun in his dissent:

Article 33.I is clear not only in what it says, but also in what it does not say: It does not include any geographical limitation. It limits only where a refugee may be sent 'to', not where he may be sent from. This is not surprising, given that the aim of the provision is to protect refugees against persecution. ${ }^{62}$

This decision demonstrates that the canon of good faith and liberal interpretation had lost all of its attraction. The admonition of Justice Field that 'words are to be taken in their ordinary meaning, as understood in the public law of nations, and not in any artificial sense impressed upon them by local law', was deliberately ignored.

\section{I.3. A comeback of liberal interpretation?}

As of today, there are indications that the Supreme Court's attitude towards treaty interpretation is changing again. In the 2010 case of Abbott v. Abbott, ${ }^{63}$ the court's majority used language reminiscent of the canons of good faith and liberal interpretation. In this case, the court was called upon to interpret the scope of the Hague Convention on the Civil Aspects of International Child Abduction, an international treaty dealing with the issue of cross-border custody disputes; in particular, the Convention provides for the immediate return of a child that has been wrongfully removed by a parent from its country of habitual residence.

In Abbott, the petitioner was a British national who had lived with his American wife and their minor son in Chile. After the parents divorced, the competent Chilean family court granted the mother the sole right of custody, while the father was awarded visitation rights. These visitation rights implied under Chilean law that the court imposed a ne exeat order, meaning that the mother could not bring the child outside the country without the father's, or alternatively the court's, permission. In violation of this ne exeat, the mother travelled with her son to Texas, where she settled

60 Sale v. Haitian Centers Council, Inc., 509 US I 55, I80 (I993).

6 I Bederman, supra note 46 , at 275.

62 Haitian Centers (Blackmun J. dissenting), at 193.

63 Abbott v. Abbott, I30 S.Ct. I983 (2010). 
with the child. Mr Abbott sued his former wife in US courts, seeking return of his son to Chile under the Hague Convention. When the case reached the US Supreme Court, the sole question was whether Ms Abbott had wrongfully removed the child within the meaning of Article 12 of the Convention, as this would require the US authorities to order the son's immediate return. Article 3 of the Hague Convention defines a wrongful removal as a removal 'in breach of rights of custody attributed to a person', whereas Article 5 specifies rights of custody as 'rights relating to the care of the person of the child and, in particular, the right to determine the child's place of residence'. Now the court had to decide whether the ne exeat order bestowed on Mr Abbott a right of custody. In Abbott v. Abbott, the Supreme Court was not divided along the usual ideological faultlines but rather right across them. This case saw Justices Stevens, Thomas, and Breyer united in dissent, while Justices Roberts, Scalia, Ginsburg, Alito, and Sotomayor joined the majority opinion authored by Justice Kennedy.

In the decision, Justice Kennedy started by conducting a (con)textual analysis of the relevant provisions, particularly the definition of custody in Article 5, and concluded that Mr Abbott's ne exeat right was a right to 'determine the child's place of residence' as well as a 'right related to the care' of his son, stressing that the Convention's 'broad' definition of custody had to override narrower understandings in order to bring as many cases as possible within the purview of the Convention's return remedy. ${ }^{64}$

He did not, however, bother to discuss the fact that the Convention draws a careful distinction between rights of custody and rights of access, providing a distinct, lesser remedy for violations of the latter; an omission that Justice Stevens took issue with in his dissent. Kennedy went on to affirm the conclusion of his textual analysis by invoking evidence from different sources: first, he relied on the view of the State Department, citing the 'well established canon of deference to the executive' in treaty interpretation. ${ }^{65}$ His argument in favour of the deference canon, that the executive branch possesses a greater insight 'in delicate matters of international relations', is questionable in an area like international family law, which is at least as much the domain of the judiciary as of the executive. ${ }^{66}$

Kennedy then turned to the practice of the other parties to the Hague Convention, stressing the need for a 'uniform international interpretation' that was also acknowledged by Congress in the statute implementing the treaty. ${ }^{67}$ In analysing the case law of other state parties, Kennedy found 'broad acceptance' for his conclusion that a ne exeat right amounted to a right of custody under Article 3 of the Convention; he cited decisions from the United Kingdom, Germany, South Africa, Austria, and

\footnotetext{
64 I30 S.Ct. I983, at 1993.

65 Ibid.

66 See for experiences of different state parties with the implementation of the Hague Convention, e.g., N. Lowe, 'The I980 Hague Convention on the Civil Aspects of International Child Abductions: An English Perspective', (2000) 33 NYU Journal of International Law and Politics I79; K. Siehr, 'The I980 Hague Convention on the Civil Aspects of International Child Abductions: Failures and Successes in German Practice',(2000) 33 NYU Journal of International Law and Politics 207; M. Bailey, 'Canada's Implementation of the I980 Hague Convention on the Civil Aspects of International Child Abduction', (2000) 33 NYU Journal of International Law and Politics I7. 
Israel. Admitting that Canadian courts held a different view, and that French courts were divided, he distinguished these unfavourable decisions, concluding that they did not address exactly the situation at hand. Then he raised an interesting question of intertemporality, noting that joint custodial arrangements had previously been unknown in many contracting states, whereas he alleged the existence of a 'growing international consensus’ acknowledging ne exeat rights as rights of custody.

In the last part of his majority opinion, Kennedy resorted to teleology, asserting boldly that the Convention's object and purpose, 'to deter child abductions', required judges 'to avoid a common tendency to prefer their own society and culture, a tendency that ought not interfere with objective consideration of all the factors'. ${ }^{68}$ He concluded with praise for the role of domestic judges in the administration of international law:

This judicial neutrality is presumed from the mandate of the Convention, which affirms that the contracting states are '[f]irmly convinced that the interests of children are of paramount importance in matters relating to their custody.' ... International law serves a high purpose when it underwrites the determination by nations to rely upon their domestic courts to enforce just laws by legitimate and fair proceedings. ${ }^{69}$

The dissenters in Abbottforged an unlikely alliance between a moderate conservative (or conservative liberal, Stevens), an originalist (Thomas), and a liberal pragmatist (Breyer). Justice Stevens, writing for the dissenters, sharply dismissed the majority's textual analysis. He argued that Mr Abbott's ne exeat right could not possibly be described as a right of custody under Article 3 and Article 5 of the Hague Convention, as it had been granted solely to protect his visitation right, which Stevens equated to a right of access under Article 5; as such, it did not trigger the return remedy. In stressing this differentiation, he extensively relied on the travaux préparatoires of the Convention. Concluding that the text was unambiguously clear, Stevens pungently attacked the majority's reliance on the State Department's view and the foreign judgments. He rejected the canon of executive deference as inapplicable and warned against 'substitut[ing] the judgment of other courts for our own'.70

Interestingly, he did not only question the existence of a current international consensus as to the issue of ne exeat rights being rights of custody; even under the assumption that such consensus had emerged, he was not willing to take that development into account:

Even assuming that the Court is correct that consensus has emerged after the Convention was written and ratified that ne exeat rights should be 'rights of custody,' in my view this provides no support at all for the position that the Convention's drafters had these types of rights in mind and intended for the Convention to treat them as rights of custody. ${ }^{7 \mathrm{I}}$

68 Ibid., at 1996.

69 Ibid., at 1996.

$70 \quad$ Ibid., at 2009.

7 I Ibid., at 2009 (at note I3). 
This is certainly an interesting move for a justice who had not been known as an originalist beforehand. ${ }^{72}$ Apparently, treaty cases have the potential to blur the usual ideological front lines. Despite the fact that Justice Stevens had referred to Article 32 VCLT to criticize the majority's reference to extratextual sources notwithstanding the lack of ambiguity, he did not generally follow the Vienna rules, nor did he seem to be aware of the concept of 'subsequent practice', as provided for in Article 3 I(3)(b) of the Vienna Convention.

Looking at the Abbott case as a whole, it can be said that both majority opinion and dissent are deeply rooted in the tradition of American treaty interpretation, with all its advantages and pitfalls. The majority seems engaged in a careful attempt to resuscitate the canon of good faith and liberal interpretation, given its repeated emphasis on the importance of a wide international understanding of the treaty terms. From a pragmatist point of view, this new-old approach has the potential to reduce international irritations created by parochial readings of international agreements. As this case dealt solely with private rights, however, it has to be seen whether the Court will continue to apply this canon when individual rights are invoked against the state. ${ }^{73}$

Also, the use of foreign decisions by the majority, as well as the weight assigned to them, reduces the likelihood of judicial unilateralism such as the one seen during the Rehnquist era. Yet the dissent is correct in pointing to the inconsistencies of the majority's approach; and the question of the threshold of ambiguity required to permit recourse to extratextual sources of interpretation has not yet been conclusively answered by the Supreme Court. The canon of executive deference is certainly a two-edged sword: it may well be desirable that the Supreme Court be informed by the State Department's assessment of the possible consequences a certain decision may have for US relations with its treaty partners; it is, however, a dangerous move when the Court starts to collude with the executive to reduce the scope of the rights of individuals under international instruments.

Probably the most challenging question posed by Abbott and like cases is not limited to the US Supreme Court, but is in fact a general problem of treaty interpretation, particularly present in the case of subsequent practice: how many states are required for a 'growing international consensus' to which a court ought to defer? This question, a matter of dispute between majority and dissent in Abbott, shows that the methodology of 'comparative international law'74 is still in its infancy. As Justice Blackmun once observed, 'modern jurists are notably lacking in the diplomatic experience of early Justices like John Jay and John Marshall, who were familiar with the law of nations and comfortable navigating by it'. ${ }^{75}$ But since it is required by strategic considerations as well as a 'decent respect to the Opinions of Mankind'76 that

72 Although the motives for adopting an originalist position under international law may arguably be different from those of constitutional originalists.

73 P. B. Stephan raises the same question in his brief comment on the case: 'Abbott $v$. Abbott: A New Take on Treaty Interpretation by the Supreme Court', (20I0) I4 ASIL Insight Issue 24.

74 On this concept see M. Koskenniemi, 'The Case for Comparative International Law',(2009) 20 Finnish Yearbook of International Law I; Roberts, supra note 7.

75 H. Blackmun, 'The Supreme Court and the Law of Nations', (1994) ro4 Yale Law Journal 39, at 49.

76 See the Declaration of Independence (I776): 
national courts applying international law shall explain their actions and justify them, it can be wondered whether the US Supreme Court will eventually embrace a more internationalist approach to treaty interpretation. The decision in Abbott offers some hope that the Supreme Court under Chief Justice Roberts could be willing to reconsider its interpretative precepts in order to adjust to an internationally more accepted 'language' of treaty interpretation.

\subsection{Treaty interpretation by Mexican courts}

Until the mid-I990s, the relationship of Mexican courts with international law was a distant one, mostly dealing with extradition treaties and constrained to narrow analyses of the treaties' internal validity vis-à-vis constitutional norms. Federal judges (jueces de distrito) in amparo proceedings ${ }^{77}$ usually applied extremely formalistic criteria for determining the validity of said treaties, whereas the highest court, the Supreme Court of Justice of the Nation (SCJN or Supreme Court), used to analyse (and affirm) the treaties' constitutionality on the basis of more systemic and teleological interpretations of the Mexican Constitution..$^{78}$ In the few cases a treaty found its way to the federal tribunals or to the Supreme Court, these judicial bodies were much more concerned with the status of treaties within the hierarchy of sources of the national legal order ${ }^{79}$ than with the interpretation of their content. If interpretation of treaty norms occurred, it used to be strictly literal, or (con)textual at most.

\subsection{Mexico's transition to democracy and the new attitude of the judiciary towards international law}

As many other things in Mexico, the judicial approach described above began to change by the mid-r99os, due in part to the newly experienced economic integration of North America, but mostly to the democratic shift of the country. A major judicial reform in 1995 considerably extended the competences of the Supreme Court with respect to questions of constitutional control. ${ }^{80}$ In relation to treaties,

When in the Course of human Events, it becomes necessary for one People to dissolve the Political Bands which have connected them with another, and to assume among the Powers of the Earth, the separate and equal Station to which the Laws of Nature and of Nature's God entitle them, a decent Respect to the Opinions of Mankind requires that they should declare the causes which impel them to the Separation.

77 On this protective judicial remedy of constitutional rights, originally from Mexico and common to several Latin American states, see A. R. Brewer-Carías, Constitutional Protection of Human Rights in Latin America: A Comparative Study of Amparo Proceedings (2008).

78 See J.C.Tron Petit, 'La Aplicación de los Tratados Internacionales por los Tribunales Mexicanos', in Universidad Nacional Autónoma de México (UNAM)/The American Society of International Law (ASIL) (eds.), El Papel del Derecho Internacional en América, La Soberanía Nacional en la Era de la Integración Regional (I997), I43 at I52-4. Art. I33 of the Mexican Constitution establishes the 'supreme law of the land' formula:

This Constitution, the laws of Congress which are made in pursuance thereof, and all the treaties which are made and will be made by the President of the Republic, with the approval of the Senate, and which are in accordance with it [the Constitution], shall be Supreme Law of the entire Union.

See Constitución Política de los Estados Unidos Mexicanos, available at www.diputados.gob.mx/ LeyesBiblio/pdf/r.pdf (last visited 2 March 2013). Translation by the authors.

80 The reform was published on 3 I December I994, the same month President Zedillo took office, and came into force on I January r 995. See Diario Oficial de la Federación (DOF), 3 I December I 994, 2. For an overview, see 
the most important aspect of the reform was the creation of the 'action of unconstitutionality' (acción de inconstitucionalidad), i.e. an abstract and a posteriori review of the constitutionality of federal and state laws as well as of treaties. However, it would be too simplistic to say that it was only a matter of time for the Supreme Court and federal tribunals to gain the much-needed self-confidence to put the new rules into effect. The overall democratization of the country was crucial in order for the courts to operate as a truly independent power. ${ }^{8 \mathrm{I}}$

The cases we will be dealing with here, which show a more autonomous, sometimes even self-opinionated attitude of Mexican judges towards international law, were all decided after the transition to democracy culminated in the presidential election of $2000 .{ }^{82}$ This new attitude has experienced and is still undergoing its own evolution, which in some instances may reflect broader juridical as well as socio-political and cultural developments of the country and beyond, and in others is probably just part of internal processes of the courts. It is plausible to distinguish between two phases of this ongoing evolution: an initial period of assimilation which was then followed by a phase of self-assertion.

\subsubsection{The need for assimilation}

After a long time of relative abstention from questions of international law, Mexico's Supreme Court needed first to engage in an 'assimilation period'. In this phase, which coincided roughly with the first five years after the presidential election of 2000, the Supreme Court developed its new approach to international law by establishing the broad lines for treaty interpretation in the domestic legal system. A respectful though distant attitude was still perceivable in a ruling of $2002,{ }^{83}$ which resulted from a case of alleged inconsistencies of certain provisions of the Federal Customs Law with Article VII of the General Agreement on Tariffs and Trade (GATT I 994). ${ }^{84}$ Here, the Supreme Court determined that in order to 'unravel the scope' of a treaty provision, the rules of interpretation of the Vienna Convention 'must' be followed, further emphasizing that these rules 'bind the Supreme Court'. ${ }^{85}$ Certainly, this approach was informed by the traditional self-understanding of most Latin American courts as organs of the state which have the duty not to breach the international obligations of their respective states. Accordingly, this reasoning need not be exclusively owed to a newfound acceptance of international law, but can also be seen as a reminiscence of the old self-perception of the SCJN as subordinated to the federal executive to which deference was owed in questions of international law.

H. Fix-Fierro, 'Judicial Reform in Mexico: What Next?', in E. G. Jensen and T. C. Heller (eds.), Beyond Common Knowledge: Empirical Approaches to the Rule of Law (2003), 240.

8I See P. Navia and J. Ríos-Figueroa, 'The Constitutional Adjudication Mosaic of Latin America', (2005) 38 Comparative Political Studies I88, at I 96.

82 There is much debate about the different phases of this transition and when exactly it ended, if at all; see further J. Woldenberg, Historia Mínima de la Transición Democrática en México (20I2).

83 SCJN, ga Época, 2a Sala, Semanario Judicial de la Federación y su Gaceta (SJFyG), XVI, 292, Tesis CLXXI/2002 (December 2002).

84 I994 General Agreement on Tariffs and Trade, I867 UNTS I87.

85 See SCJN Tesis CLXXI/2002, supra note 83. 
But the Court also interpreted the Vienna rules of interpretation in its GATT case. Although the SCJN first limited itself to explaining them by restating their content, it made three noteworthy clarifications: first, it ruled that recourse to Articles $3 \mathrm{I}$ and 32 VCLT was subject to Article I4, paragraph 4 of the Mexican Constitution, which establishes the principle of legality in non-military trials and gives strict priority to the method of literal interpretation. ${ }^{86}$ It thereby somehow ascribed a primacy to textual interpretation, which seems to go beyond what Article 3I(I) VCLT says. Second, it 'translated'87 the said provision into its own hermeneutics terminology of 'literal', 'systemic', and 'teleological' interpretations. ${ }^{88}$ And finally, the SCJN underlined the separation of Articles 3I and 32 VCLT by stating that 'in principle, one shall not turn to the preparatory works of a treaty nor to the circumstances surrounding its conclusion' 89

Even if it is hard to imagine how, in a concrete case, the application of Articles 3 I and 32 VCLT could run counter to Article I4 of the Constitution, in that initial period of a new international openness, it was necessary for the Court to reaffirm its primary role as the guardian of Mexico's magna carta. Although the Court's rigid reading of the relationship between Articles 3 I and 32 is compatible with the VCLT, taken together with its emphasis on literal meaning and the safeguard made in relation to the Mexican Constitution, it denotes its hermeneutical preference at that time, and, arguably, a lack of experience with treaty interpretation. One cannot help but to be reminded of the concerns expressed by Myres S. McDougal at the Vienna Conference, namely that said separation could lay a predominant emphasis on a purely literal approach, leading thus the interpreter to futilely focus on the 'ordinary meaning' of the text. ${ }^{90}$

In the following years, these standards began to be applied by federal tribunals and the Supreme Court itself, and as is common in learning processes, the use of the Vienna rules and the Court's interpretation of them have been rather inconsistent. An interesting example is the Cavallo case of 2003, where the extradition of an Argentinian citizen - and former army officer - to Spain on the basis of universal jurisdiction for the crimes of genocide and terrorism allegedly committed during the military regime in Argentina was confirmed by the Supreme Court. ${ }^{91}$ Here, reference was made to the ruling on treaty interpretation of 2002. However, one of the few proper interpretations performed by the SCJN of the treaties at hand, namely that regarding Article II of the I948 Convention on the Prevention and

86 See Constitución Política de los Estados Unidos Mexicanos, supra note 79.

87 Borrowing the expression from Knop, supra note 7.

88 See SCJN Tesis CLXXI/2002, supra note 83: 'This [Article 3I(I) VCLT] means that recourse to the methods of literal, systemic and teleological interpretation shall be made'.

89 Ibid.

90 See UN Conference on the Law of Treaties, Summary Records of the Plenary Meetings and of the Meetings of the Committee on the Whole (Official Records), First Session, Vienna, 26 March-28 May 1968, (I969), I67-8, paras. 38-50; see also Gardiner, supra note 27, at 303-6.

9I SCJN, Amparo en revisión I40/2002 (Io June 2003). See M. Becerra Ramírez, 'El Caso Cavallo', (2004) 4 Anuario Mexicano de Derecho Internacional (AMDI), 585; V. Thalmann, 'National Criminal Jurisdiction over Genocide', in P. Gaeta (ed.), The UN Genocide Convention: A Commentary (2009), 231, at 256. Ricardo Miguel Cavallo was sentenced to life prison by a federal tribunal in Argentina; see Tribunal Federal No. 5, sentencia 26 de Octubre de $20 I I$. 
Punishment of the Crime of Genocide ${ }^{92}$ and the alleged political nature of the crime, was reached through the analysis of the drafting history of the said Convention in the Sixth Committee of the UN General Assembly, without first resorting to the general rule on interpretation of the Vienna Convention, or otherwise justifying immediate recourse to its Article 32. In particular, the Supreme Court recalled a proposal to add to the elements of the crime of genocide racial, religious, or political motivations, which was rejected by the delegation of the United Kingdom on the basis that the intention to destroy, totally or partially, a national, ethnic, or religious group was the constitutive element of the crime, regardless of the motivation of the perpetrator. ${ }^{93}$ The Supreme Court deviated thus from the excessive literal approach it had proclaimed just the year before.

In a case from $2004^{94}$ related to intellectual property rights contained in the 1883 Paris Convention for the Protection of Industrial Property, ${ }^{95}$ in the I 994 Agreement on Trade Related Aspects of Intellectual Property Rights (TRIPS), ${ }^{96}$ and in NAFTA, ${ }^{97}$ the highest Court once again acknowledged the Vienna rules on interpretation. However, in contrast to the 2002 GATT case, this time the Court did not talk any more of an obligation to apply the Vienna rules, but said that these 'shall be pondered' ${ }^{98}$ Furthermore, the Court embraced a moderate dualist approach to international law in order to emphasize that treaties do not have a direct effect in Mexican law. After doing this, it arrived rather oddly at the conclusion that, given the fact that treaties undergo a process of approval by the Senate and publication in the official federal gazette, they enjoy a presumption of constitutionality. It is interesting to see how the Court found it necessary to refer to international doctrine in order to deny direct effect to treaties, ${ }^{99}$ and at the same time connected this denial to a relatively treaty-friendly interpretative guideline.

One of the cases that has caught the broadest public attention in Mexico in the recent history of the Supreme Court is the Halcones case, ${ }^{\text {Ioo }}$ related to the killings of students during the Dirty War of the r970s at the hands of paramilitary-like commandos. The judgment of June 2005 has been much criticized by human rights groups and academia, ${ }^{\text {IOI }}$ inter alia, because it declared that, according to the Constitution and the interpretative declaration made by Mexico when ratifying the I 968 Convention on the Non-Applicability of Statutory Limitations to War Crimes and Crimes against Humanity, ${ }^{\text {IO2 }}$ the said Convention could not apply retroactively to

92 I948 Convention on the Prevention and Punishment of the Crime of Genocide, 78 UNTS 277.

93 See supra note 9I.

94 SCJN, Amparo en revisión 237/2002 (2 April 2004).

95 I 883 Paris Convention for the Protection of Industrial Property, 828 UNTS 305.

96 I 994 Agreement on Trade Related Aspects of Intellectual Property Rights, I869 UNTS 299.

97 I 994 North American Free Trade Agreement, (I993) 32 ILM 289, 605.

98 See supra note 94.

99 For a different approach to this issue, see infra section 3.3.3.

Ioo SCJN, Recurso de Apelación I/2004-PS Derivado de la Facultad de Atracción 8/2004-PS (I5 June 2005).

IOI See, e.g., M. Becerra Ramírez, 'Comments on the Mexican Supreme Court of Justice Ruling on the Halcones Case', (2007) 8 (Old Series) Mexican Law Review; J. Dondé Matute, 'The Duty to Prosecute Human Rights Violations before the Supreme Court of Mexico', (2009) I 24 Boletín Mexicano de Derecho Comparado, I9I.

I02 I968 Convention on the Non-Applicability of Statutory Limitations to War Crimes and Crimes against Humanity, 754 UNTS 73 . The interpretative declaration can also be found at 754 UNTS 73. 
its entry into force for Mexico, i.e. before 22 April 2002. ${ }^{103}$ In an individual vote (voto particular), which in fact constitutes a dissenting opinion, Justice Silva Meza, today's president of the Court, declared that the principle of non-retroactivity contemplated in the Constitution was not applicable to the Convention, to which Mexico had acceded by virtue of its sovereign consent. Mexico had thus an obligation towards the international community to interpret this treaty in conformity with its object and purpose. He referred to the Vienna rules and the 2002 GATT case in order to determine that the interpretative declaration of Mexico was contrary to the object and purpose of the Convention, and, therefore, should have been declared void by the Court. ${ }^{\text {I04 }}$ The contrast to the attitude of complete deference to the executive reigning in Mexico until the mid-I99os and still visible in the early years of democracy is clear: loyalty was now owed to the international community. The individual vote of Justice Silva Meza can be regarded as signalling the transition to the next step identified here, which arguably reflects a much broader development of judicial self-assertion in Mexico and in other Latin American countries. ${ }^{105}$

\subsubsection{The need for self-assertion}

Today Mexican tribunals are delineating their way of dealing with treaties. A tendency can be observed according to which the propersona principle is being extended continuously. This is, in part, the consequence of the constitutional reform of June $20 \mathrm{II},{ }^{106}$ whereby human rights contained in treaties to which Mexico is a party are placed at the highest level along with the Constitution, and the pro persona principle is recognized, together with that of consistent interpretation, as the hermeneutical framework for Mexican judges when confronted with human rights (Article I of the Mexican Constitution). ${ }^{\text {I07 }}$ However, this trend was already present at the Mexican judiciary before June 20I I. Directly influenced by the jurisprudence of the Inter-American Court of Human Rights (IACHR) and some national courts in Latin America, federal tribunals began to apply this interpretational approach as early as $2004 .{ }^{108}$

Be that as it may, after the reform of June 20 I I and a paradigmatic resolution of the Supreme Court issued only a month later on the occasion of questions related to

I03 The Convention was signed on 3 June I969, ratified on I5 March 2002, and published in the official federal gazette on 22 April 2002; see DOF, 22 April 2002, IO.

I04 The individual vote restated Justice Silva Meza's original draft of the ruling, which was rejected by the majority of the Court's Second Chamber on 9 March 2005. See Ponencia del Ministro Juan Silva Meza, Proyecto de Recurso de Apelación I/2004-PS derivado de la Facultad de Atracción 8/2004-PS (23 February 2005).

I05 Also relating Silva Meza's vote with the then emerging preference of the pro persona principle, see J. Dondé Matute, 'El Derecho Internacional y su Relevancia en el Sistema Jurídico Mexicano: Una Perspectiva Jurisprudencial', (2009) 9 AMDI, I9I, at note 4I.

Io6 See DOF, Io June 20I I, 2. For a first comprehensive study on the reform, see M. Carbonell and P. Salazar (eds.), La Reforma Constitucional de Derechos Humanos: Un Nuevo Paradigma (20 I I), 449.

I07 See supra note 79.

Io8 Dondé Matute refers to a case of 2004 of the Fourth Collegiate Tribunal on Administrative Matters for the First Circuit dealing with the dismissal of a member of the armed forces who had been tested HIV-positive, supra note I05, at 205-8. 
the implementation of the Radilla judgment of the IACHR, ${ }^{\mathrm{I} 09}$ the pro homine or pro persona principle - as the SCJN prefers - is today the undisputed maxim regarding the interpretation of human rights treaties. In its opinion on this case, the Supreme Court stated that every public authority in Mexico, including the entire judicial system, shall always opt for the most favourable interpretation of the human right under consideration, be it a human right established in the Constitution or in a treaty to which Mexico is a party. ${ }^{\text {IIo }}$ Following this opinion, in a ruling of January 2012, the Court went significantly further by mentioning that

the norms related to human rights shall be interpreted in conformity with the Constitution itself and with international treaties to which Mexico is a party, in a way that broadly favours persons. This translates into the obligation to analyze content and scope of such rights on the basis of the pro persona principle, a hermeneutical criterion which informs the whole international law of human rights, and according to which the widest norm or the most extensive interpretation has to be applied ... ${ }^{\text {II }}$

The pro persona principle is as intuitive as it is tautological. It could be argued that it is the object and purpose of every human rights treaty to grant the broadest possible protection to each of the rights it contains, ${ }^{\text {II2 }}$ and that everything else would run counter to their very normative function. The limits of this principle become apparent when human rights of different individuals have to be balanced. In any case, since the determination of the human rights nature of specific treaty norms is again a matter of treaty interpretation, the application of the pro persona principle can lead to a very wide extension of its own scope. There is the risk of looking at every treaty provision entailing rights or otherwise affecting the legal situation of individuals through the lenses of human rights.

In what has become another frequent tool of treaty interpretation related to the pro persona principle, Mexican tribunals - like many of their peers in Latin America $^{\mathrm{II} 3}$ - rely more and more on the interpretations of the IACHR, also for questions which concern treaties which are not part of the Inter-American system. For instance, the finding of the San José Court that Article 36(I)(b) of the Vienna Convention on Consular Relations ${ }^{\text {II } 4}$ belonged to the category of human rights ${ }^{\text {II } 5}$

Io9 SCJN, Pleno, Varios 9i2/20Io (I4 July 20II), reprinted in DOF (4 October 20II), Segunda Sección, 5I. This resolution is not binding, but rather a sort of opinion of the Court as a whole, which exerts a strong persuasive power on Mexican judges.

I Io Ibid., para. 27.

I I I SCJN, Ioa Época, Primera Sala, tesis aislada XXVI/20I2, V SJFyG (February 20I2), 659. Translation by the authors; emphasis added.

I 2 In a concurrent opinion, former Mexican Judge of the IACHR, Sergio García Ramírez, relates the pro homine principle contemplated in Article 29 of the ACHR to the object and purpose of the Convention by making express reference to Article 3 I (I) of the VCLT. See IACHR, Case of the Mayagna (Sumo) Awas Tingni Community v. Nicaragua, Merits, Reparations and Costs, Judgment (3 I August 200I), Series C, No. 79, Concurring Opinion of Judge Sergio García Ramírez, at para. 2. On pro persona beyond the Inter-American system, see L. Crema, 'Disappearance and New Sightings of Restrictive Interpretation(s)', (2010) 2I EJIL 68I, at 688-9I.

I 3 See, e.g., C. Binder, ¿Hacia una Corte Constitucional de América Latina? La Jurisprudencia de la Corte Interamericana de Derechos Humanos con un Enfoque Especial Sobre las Amnistías', in A. von Bogdandy, E. Ferrer Mac-Gregor, and M. Morales Antoniazzi (eds.), La Justicia Constitucional y su Internacionalización ¿Hacia un Ius Constitutionale Commune en América Latina? (2010), Vol. II, I59.

I 4 I 963 Vienna Convention on Consular Relations, 596 UNTS 26I.

I 5 See IACHR, The Right to Information on Consular Assistance in the Framework of the Due Process of Law, Advisory Opinion, OC-16/99 (I October I999), Series A, No. I6, in particular operative clause 2. 
was followed by a Mexican federal tribunal, while noting the widespread use of the San José jurisprudence by other courts in the region. ${ }^{\text {II } 6}$ This decision of 2007 was echoed recently by the Supreme Court in the politically controversial case of Florence Cassez which involved a French citizen sentenced to 60 years in prison for kidnapping. ${ }^{\text {II } 7}$ On 23 January 20I $3,{ }^{\text {II } 8}$ the Court's First Chamber voted in favour of a draft previously prepared by Justice Zaldívar ${ }^{\mathrm{II} 9}$ and ordered the immediate release of Florence Cassez. The draft reproduced the IACHR interpretation of Article 36 of the Vienna Convention as being 'part of the corpus iuris of contemporary international human rights law', and erroneously sought further support for this position in the 2004 Avena decision of the ICJ. ${ }^{\mathrm{I} 20}$

The tautological nature of the propersona principle not only leads to an expansion of its scope of application, it also tends to inflate its own meaning. Other competing considerations are not truly considered and every other method of interpretation is finally subordinated to the pro persona maxim. A case in point is a recent judgment of Mexico's Supreme Court in relation to the right to have a name. ${ }^{\text {III }}$ Here, a person wanted to change his double surname, asking for the deletion of its second part. Administrative authorities and judges of the state of Aguascalientes consistently refused to make the change, since the state's Civil Law Code establishes strict restrictions to this procedure which the original petition clearly did not meet. When the case reached the SCJN, the plaintiff claimed that its human right to change her/his name on the basis of Article I8 of the American Convention on Human Rights (ACHR) was violated. This Article states:

Every person has the right to a given name and to surnames of his parents or that of one of them. The law shall regulate the manner in which this right shall be ensured for all, by the use of assumed names if necessary. ${ }^{\mathrm{I22}}$

The plaintiff argued in particular that the lower courts had failed to interpret Article I 8 in the light of the pro persona principle, as was allegedly required under Article I of the Mexican Constitution. In its ruling from January 20I2, the First Chamber of the SCJN engaged in an analysis of the meaning and scope of the human right to have a name established in Article 29 of the Constitution (which does not say much) and 'in light of the international commitments acquired by the Mexican

I 6 Primer Tribunal Colegiado del Segundo Circuito en Materia Penal, Amparo directo 98/2007. See Dondé Matute, supra note I05, at 2I I-I5.

II7 See 'Hollande: "Une période particulièrement douloureuse prend fin”, Le Monde.fr, 23 January 20I3, available at www.lemonde.fr/ameriques/article/2013/01/23/hollande-une-periode-particulierementdouloureuse-prend-fin_I82I5I6_3222.html (last visited 4 March 2013); see also M. Delgado, 'Reciben a Cassez con Otro Montaje', Reforma, 24 January 2013.

II 8 At the time of writing, the ruling has not been published; see, however, the records of the public hearings at SCJN, Primera Sala, Sesión Pública, Acta Número 3, 23 January 2013, available at www.scjn.gob.mx/Primera_Sala/Ira_listas_actassesion/ActaSesPub20I30I 23.pdf(last visited 4 March 20I3).

I 9 See Ponencia del Ministro Arturo Zāldívar Lelo de Larrea, Proyecto de Resolcuión en el Amparo directo en revisión 5I7/20II.

I20 On that occasion, the ICJ stated: 'Whether or not the Vienna Convention rights are human rights is not a matter that this Court need decide'. Case Concerning Avena and Other Mexican Nationals (Mexico v. United States of America), Judgment of 3I March 2004, [2004] ICJ Rep. I2, paras. I24-I 25.

I2 I SCJN, Amparo en revisión 2424/20I I (I8 January 20I2).

I22 I969 American Convention on Human Rights, I I44 UNTS I 23. 
State on the matter'. ${ }^{\text {I23 }}$ Then, the Court clarified that in conformity with the newly amended Article I of Mexico's fundamental law, the constitutionally guaranteed right to a name must indeed be interpreted in accordance with the pro persona and the systemic interpretative methods. The latter was then defined following the IACHR jurisprudence, which has consistently stated that the interpretation of a treaty should take into account not only the agreements and documents directly related to it (paragraph two of Article 3I of the Vienna Convention), but also the system of which it is a part (paragraph three of Article 3 I of this Convention)'. ${ }^{\text {I24 }}$

The Mexican Court, however, limited the 'normative environment' which shall be taken into account in the interpretation of human rights treaty norms to those norms of the 'same nature', making thus a questionable interpretation of the San José Court's obiter dicta on systemic integration, and thereby of Article 3I(3)(c) itself. But beyond that, it is not clear how the several treaty norms to which the Court referred, such as Article 24(2) of the ICCPR, ${ }^{\mathrm{I} 25}$ Article 8 of the ${ }^{\mathrm{I}} 989$ Convention on the Rights of the Child, ${ }^{\mathrm{I} 26}$ and Article I6(g) of the I979 Convention on the Elimination of All Forms of Discrimination against Women, ${ }^{\mathrm{I} 27}$ are relevant for the claim that Article I 8 of the ACHR entails a right to change the name. The Court then brought in the interpretation of the IACHR. In two cases, Yean and Bosico v. Dominican Republic ${ }^{\mathrm{I}} 8$ and 'Las Dos Erres Massacre' v. Guatemala, the latter has established that the right contained in Article I 8 entails the guarantee by the state

that a person is registered with the name chosen by that person or his/her parents, depending on the time of the registration, without any sort of restriction on the right nor interference with the decision to choose a name. Once the person is registered, their possibility to preserve and re-establish their name and surname should be guaranteed. ${ }^{129}$

The SCJN then resorted, in a rather automatic modus, to the pro persona principle, transforming the 'authorized interpretation' of the San José Court into the following formula: 'once the person is registered, the possibility to preserve or modify their name and surname shall be guaranteed'. ${ }^{30}$ This new interpretation (modification?) of the right to have a name applies directly only to Article 29 of the Mexican Constitution, but it is based, according the Court, on the pro persona interpretation and the systemic integration of Article 18 of the American Convention; one might add on the pro persona interpretation of Article 3I(3)(c) of the VCLT. The result not only is highly questionable from the systemic perspective of international law, as well as from that of Mexico's federal system, it also might be hard to sustain by even the most fervent defenders of the pro homine principle in San José.

\footnotetext{
I23 Supra note I2I, para. 28.

I24 Ibid., para. 46, referring to the Mapiripán Massacre v. Colombia and Yakye Axa v. Paraguay cases (both 2005), as well as to the advisory opinion OC-I6 of I 999.

I 25 I 966 International Covenant on Civil and Political Rights, 999 UNTS I 7 I.

I26 I989 Convention on the Rights of the Child, I 577 UNTS 3.

I27 I979 Convention on the Elimination of All Forms of Discrimination against Women, I 249 UNTS I 3.

I 28 See IACHR, Case of the Girls Yean and Bosico v. Dominican Republic, Judgment (8 September 2005), Series C, No. I30, paras. I8I et seq.

I 29 IACHR, Case of Las 'Dos Erres' Massacre v. Guatemala, Judgment (24 November 2009), Series C, No. 2 I I, para. I92.

I30 Supra note I2I, para. 57. Translation by the authors, emphasis added.
} 
We have thus seen that in the past twelve years, the Mexican Supreme Court and some federal tribunals have moved from a rather passive and discrete to a more active, and in more recent cases even self-opinionated, attitude towards the interpretation of treaties. Narrow formalistic concerns regarding constitutional treatymaking powers and the place of treaties within the domestic legal order were set aside, allowing for a dynamic understanding of the treaties' normative contents. Although the Supreme Court initiated this new phase of engagement by restating the Vienna rules of interpretation as the basic parameters of the game, it signalled almost from the beginning that the game to be played by it would also follow its own peculiarities. Accordingly, it soon diluted the strictness of these rules by clarifying that they should 'be pondered'. A dissenting opinion by today's president of the Supreme Court indicated a shift in the Court's general attitude towards the primacy of the legal protection of the individual as a universally recognized value. Today, the pro persona principle is the undisputed maxim guiding Mexican judges in the interpretation of human rights contained in the Constitution and in any treaty to which Mexico is party. Moreover, the Supreme Court is expanding the scope of this principle of interpretation to those norms related to human rights, a matter which is to be interpreted according to the same criterion. This evolution coincides with the first two terms of democratically elected presidents in Mexico, making it thus interesting to observe how the democratization process of the country has influenced the judiciary's self-perception of its own role within the sociopolitical system, and how this has played a critical role in its interpretative practice, including of treaties.

\subsection{The European Court of Justice and the interpretation of international agreements}

Another story of how domestic courts approach the issue of interpretation can be told for the European Court of Justice (ECJ). At first sight, it may be surprising to include the ECJ in this category. After all, the ECJ is a judicial organ of a regional organization established by virtue of international law. It has become more and more common, however, to regard the ECJ as being functionally equivalent to a municipal court. ${ }^{\mathrm{I} \text { I }}$ It has to deal with questions of international law in a way which is comparable to the situation in which domestic courts find themselves when they have to apply international law. Also, the ECJ has to determine the legal effects of international agreements of the EU in the EU legal system. ${ }^{132}$

Two additional reasons stand out to justify looking at ECJ practice. First, its judges have a different background compared to ordinary domestic judges. Only to a limited degree can they bring their domestic legal tradition to fruition when they decide cases. Arguably, the ECJ has developed its own interpretative culture when

I3 I See, among many other contributions, A. von Bogdandy, 'Pluralism, Direct Effect and the Ultimate Say: On the Relationship between International and Domestic Constitutional Law', (2008) 6 ICON 397, at 399.

I32 C. Eckes, 'International Law as Law of the EU: The Role of the European Court of Justice', in E. Cannizzaro, P. Palchetti, and R. A. Wessel (eds.), International Law as Law of the European Union (201 2), 353. 
it is dealing with EU law, ${ }^{\mathrm{I} 33}$ which is a blend of the different influences upon the court. ${ }^{\text {I34 }}$

Second, the jurisprudence of the ECJ with respect to international law has gone through various cycles. Traditionally the jurisprudence of the Court has been viewed as being particularly open towards international law. Its more recent case law has given rise to the question whether the ECJ is now doing things the 'European way' ${ }^{135}$ the court's refusal to grant UN Security Council Resolutions binding force within the European legal order in $\mathrm{Kadi}^{136}$ or the alleged transfer of its restrictive jurisprudence on direct effect developed in the framework of GATT/WTO obligations to other international agreements in the Intertanko decision are just two incidents which have been identified as turning points in the Court's case law on international law. ${ }^{137}$

\subsection{The Vienna rules and the distinct nature of treaties}

Although the EU (and its predecessor, the EEC/EC) is party neither to the VCLT nor to the I986 Convention pertaining to international organizations, ${ }^{\mathrm{I} 38}$ the ECJ quite frequently refers to Article 3 I of the VCLT, which it considers to represent customary international law. Already at the outset, it should be noted, however, that there are also important cases in which no such references figure - an issue to which we shall turn in due course.

The ECJ first referred to the VCLT in the I99I opinion on the creation of a special court for a 'European Economic Area' (EEA) which was to be established by the then EEC and its member states, on the one hand, and the states comprising the European Free Trade Association (EFTA), on the other. The purpose of the agreement was to extend the uniform rules of the EC common market concerning the free movement of persons and goods to the EFTA countries. For disputes arising in this respect, a new court was to be created. For the ECJ, the issue was whether the creation of this new court would undermine its own authority. Whereas the EEA court would have to pay due respect to the jurisprudence of the ECJ, the Court noted that

[t]he fact that the provisions of the agreement and the corresponding Community provisions are identically worded does not mean that they must necessarily be interpreted identically. An international treaty is to be interpreted not only on the basis of its wording, but also in the light of its objectives. Article 3 I of the Vienna Convention ... stipulates in this respect that a treaty is to be interpreted in good faith and in accordance

I33 See N. Fennelly, 'Legal Interpretation at the European Court of Justice', (I997) 20 Fordham International Law Journal 656; G. Conway, The Limits of Legal Reasoning and the European Court of Justice (2012).

I34 Cf. J. W. van Rossem, 'Interaction between EU Law and International Law in the Light of Intertanko and Kadi: The Dilemma of Norms Binding the Member States but Not the EU', (2009) 40 NYIL I83, at I 95.

I35 J. Klabbers, Treaty Conflict and the European Union (2009), I I; Eckes, supra note I32, at 363.

I36 See G. de Búrca, 'The ECJ and the International Legal Order: A Re-Evaluation', in de Búrca and Weiler, supra note 36 , ro5.

I37 See M. Bronckers, 'From “Direct Effect” to "Muted Dialogue”: Recent Developments in the European Courts' Case Law on the WTO and Beyond', (2008) I I JIEL 885, at 894.

I3 8986 Vienna Convention on the Law of Treaties between States and International Organizations or between International Organizations, (I987) 25 ILM 543. 
with the ordinary meaning to be given to its terms in their context and in the light of its object and purpose. ${ }^{\text {I39 }}$

The ECI then stressed the differences between the EFTA/EEA and the EEC legal order. Whereas the former would only create legal obligations for the member states, the EEC was based on agreements which constitute the 'constitutional charter of a Community based on the rule of law' with all the characterizing features of supranationality, i.e. direct effect and supremacy of Community law.

It has been stressed that the remarkable feature of this opinion is the Court's emphasis on the object and purpose of the treaty. ${ }^{\mathrm{I}}{ }^{\circ}$ In general international law, the reference to the object and purpose of the treaty is frequently understood to allow for a progressive, evolutive interpretation which potentially decouples a treaty from the original will of the states parties. ${ }^{\mathrm{I}}{ }^{\mathrm{I}}$ For the ECJ, however, the reference to the object and purpose of the EEA agreement served to underline the limitations of traditional international agreements as compared to the dynamic nature of Community law. The object and purpose of the EEA agreement is, then, if one follows the reasoning of the ECJ, to lead to some form of integration, albeit one which does not lead down the path to supranationality. This rhetoric of the categorical difference between the object and purpose of the founding treaties of the EC and the EU on the one hand, and international agreements which are governed by 'ordinary' international law on the other, has since then been used consistently by the Court. ${ }^{\text {I42 }}$

\subsubsection{Theory and practice of the Vienna Rules in the ECJ case law}

Despite its recurring (though not systematic) usage of the Vienna rules, the ECJ only explained in its 2010 Brita case why it has to apply the Vienna rules. The case concerned the interpretation of the association agreements between the EC and Israel and the Palestinian authorities respectively. The court held that the EC-Israel association agreement, 'having been concluded by two subjects of international law', would be 'governed by international treaty law and, more specifically, as regards its interpretation, by the international law of treaties'. ${ }^{\text {I43 }}$ The court went on to state that 'the international law of treaties was consolidated, essentially, in the Vienna Convention' and that the rules laid down in it would apply to the association agreement 'in so far as the rules are an expression of general international customary law'. This would entail that '[c]onsequently, the EC-Israel Association Agreement must be interpreted in accordance with those rules'. ${ }^{\text {I4 }}$

The court then referred to Article 3I(I) of the Vienna Convention as well as to the impact of 'any relevant rules of international law applicable in the relations between

\footnotetext{
I39 Opinion I/9I, [I99I] ECR, I-6079, para. I4.

I40 P. J. Kuijper, 'The Court and the Tribunal of the EC and the Vienna Convention on the Law of Treaties', (I998) 25 Legal Issues of European Integration I, at 2.

I4I C. Focarelli, International Law as Social Construct: The Quest for Global Justice (2012), 253; but see also R. Kolb, Interprétation et création du droit international: Esquisse d’une herméneutique juridique moderne pour le droit international public (2006), at 530 et seq.

I42 P. J. Kuijper, 'The European Courts and the Law of Treaties: The Continuing Story', in E. Cannizaro (ed.), The Law of Treaties beyond the Vienna Convention (201 I), 256, at 260 et seq.

I43 Case C-386/o8, Brita GmbH v. Hauptzollamt Hamburg-Hafen, [2010] ECR I-I 289, para. 39.

I44 Ibid., paras. 40-4I.
} 
the parties'. ${ }^{45}$ This reference to Article 3I(3)(c) of the VCLT brought the Court to the consideration of the pacta tertiis rule set forth in Article 34 of the Convention. The case revolved around the question whether Israeli customs authorities would enjoy the competence to label products which in part originated from the occupied Palestinian territories as originating from Israel, thereby bringing them within the territorial scope of application of the EC-Israel Association Agreement. This question was further complicated by the fact that the parallel agreement between the EC and the Palestinian territories also included a provision on its territorial scope of application, indicating that this agreement was meant to cover products originating from the West Bank and the Gaza strip.

The issue was thus to determine the relationship between the two agreements. The German court which had referred the case to the ECJ wanted to know, among other things, whether it was possible to make an 'elective determination', i.e. to grant preferential treatment to the goods in question in any case as they would either fall within the scope of application of the EC-Israel agreement or within the scope of the agreement between the EC and the Palestinian Authorities. This was rejected by the ECJ on the basis of Article 34 of the Vienna Convention:

to interpret Article 83 of the EC-Israel Association Agreement as meaning that the Israeli customs authorities enjoy competence in respect of goods originating in the West Bank would be tantamount to imposing on the Palestinian customs authorities an obligation to refrain from exercising the competence conferred upon them by virtue of the abovementioned provisions of the EC-PLO Protocol. Such an interpretation, the effect of which would be to create an obligation for a third party without its consent, would thus be contrary to the principle of general international law, 'pacta tertiis nec nocent nec prosunt' as consolidated in Article 34 of the Vienna Convention. ${ }^{\mathrm{I} 6}$

While the Court can be commended for its systematic explanation why it has to have recourse to the international rules of interpretation, the result of their application is somewhat stretching the scope of the pacta tertiis rule. By means of the interpretative method of systemic integration, a very broad principle of international law is brought into the equation which arguably cannot justify the outcome of the case. $^{\mathrm{I}}{ }^{77}$ Instead, it was apparently used in order to refrain from a politically more sensitive pronouncement on the limits of the notion of territory of Israel. Independently of the political prudence of this decision, this case should alert us that selfproclaimed respect for the Vienna rules of interpretation does not necessarily lead to a convincing judicial reasoning.

It should be stressed, however, that the ECJ has emphasized in its case law that resort to the Vienna rules is not a matter of choice, but that international agreements are actually governed by international treaty law and thus the international rules on interpretation. This is only consequential in light of the place that agreements of the EU occupy in its legal system. According to the long-standing jurisprudence of

\footnotetext{
I45 Ibid., para. 43 .

I46 Ibid., para. 52.

I47 Though different in many aspects, it is interesting to see how the Mexican Supreme Court also relied on the method of systemic integration without actually justifying its outcome in the case of the right to have a name; see supra section 3.2.3.
} 
the Court, agreements concluded under Article 2 I 6 of the Treaty on the Functioning of the European Union are an 'integral part' of the EU legal order. They thus apply automatically and need no act of transformation in order to produce legal effects within the EU legal order.

\subsubsection{The determination of the direct effect of treaty norms by the ECJ: between international and domestic law}

It is well known that there are exceptions to this rule. Most notably, the ECJ has refused to accord direct effect to GATT as well as WTO law. ${ }^{\text {I48 }}$ In its more recent case law, it has also made clear that decisions of the Appellate Body of the Dispute Settlement Mechanism of the WTO are not directly enforceable in the EU legal order. ${ }^{\mathrm{I} 49}$ This is owing to the various options WTO member states have to remedy breaches, as well as to the fact that other member states do not grant direct effect to GATT and WTO provisions either, which is perceived by the ECJ as a lack of reciprocity. ${ }^{150}$ In cases concerning these questions there is a conspicuous absence of references to the Vienna rules of interpretation. Whereas, as we have seen, the ECJ generally acknowledges the obligation to interpret international agreements according to the rules set forth by the Vienna Convention, they are absent from deliberations which concern the determination of direct effect of the agreements entered into by the EU.

For our purposes, it is relevant how the ECJ determines whether an international agreement has direct effect within the EU legal order or not. This is regularly done with a two-tier test which first determines whether the nature and broad logic of an agreement speak against the granting of direct effect, and second enquires whether the concrete provision which is to be applied is sufficiently clear, precise, and unequivocal. One reason for the absence of references to the Vienna rules could be that the determination of direct effect is a juridical exercise which sits at the borderline between the international and the domestic spheres. ${ }^{15 \mathrm{I}}$

The ECJ itself does not purport to measure the direct effect of international agreements in terms of EU law, however. Its enquiry into the nature and broad logic of the agreement and the concrete qualities of the respective individual rule rather point towards the assumption that the ECJ is engaging in an act of interpretation of international law when it is determining whether or not a provision has direct effect in the EU legal order. This assumption finds confirmation in the recent ATAA case of 2OI I in which the ECJ had to decide on the legality of the application of the EU emissions trading system (ETS) to air traffic and, more precisely, the fact that airlines from non-EU countries have to submit to this scheme for the entire duration

\footnotetext{
I48 Joined cases 2 I-24/72, International Fruit Company NV v. Produktschap voor Groenten en Fruit, [I972] ECR I 2 I 9.

I49 Joined cases C-I20/06 P and C-I2I/06 P, FIAMM and Fabbrica Italiana Accumulatori Motocarri Montecchio Technologies LLC et al v. Council and Commission, [2008] ECR I-65I3.

I50 B. I. Bonafé, 'Direct Effect of International Agreements in the EU Legal Order: Does It Depend on the Existence of an International Dispute Settlement Mechanism?', in Cannizaro, Palchetti, and Wessel, supra note I32, 229 , at 230.

I5 I See Nollkaemper, supra note 7, at I 24-9.
} 
of their flights if they land or depart at an aerodrome in the EU. ${ }^{152}$ Here, the ECJ noted in passing that when it has to decide on the direct effect of an international agreement entered into by the EU in the EU's internal legal order, this question falls 'to be decided by the courts having jurisdiction in that matter, and in particular by the Court of Justice, in the same manner as any question of interpretation relating to the application of the agreement in the European Union'. ${ }^{\text {I53 }}$ Despite this state of affairs, the international rules of interpretation regularly only intervene, however, once the two-tier test has been passed. ${ }^{\text {I54 }}$

At the same time, it is interesting to see to what extent the nature and broad logic of an agreement can be reconciled with the interpretative rules of the Vienna Convention. ${ }^{\mathrm{I} 55}$ Such an operation could be part of the context of a provision within the overall framework of the relevant agreement. Individual cases, however, cast a shadow of doubt in this regard. In the 2008 Intertanko judgment, the ECJ had to determine whether an EC directive on ship-source discharges of polluting substances was in contravention of the principle of freedom of navigation and innocent passage guaranteed by the United Nations Convention on the Law of the Sea (UNCLOS), ${ }^{\text {I5 }}$ to which both the EU and its member states are parties.

The claimants had argued that the EC directive established stricter standards with respect to the discharging of polluting substances than UNCLOS. In order to determine whether the UNCLOS provisions relied upon were susceptible to direct effect in the EU legal order, the ECJ had to determine whether 'the nature and broad logic of UNCLOS, as disclosed in particular by its aim, preamble and terms, preclude examination of the validity of Community measures in the light of its provisions'. ${ }^{\text {5 }} 7$ In what follows, the Court emphasized the 'main objective' of UNCLOS, i.e. the clarification and development of the general rules on the uses of marine areas. UNCLOS would generally aim to 'strike a fair balance between the interests of States as coastal States and the interests of States as flag States, which may conflict'. ${ }^{158}$ In juxtaposition to this function of UNCLOS, the Court argued:

individuals are in principle not granted individual rights and freedoms by virtue of UNCLOS. In particular, they can enjoy the freedom of navigation only if they establish a close connection between their ship and a State which grants its nationality to the ship and becomes the ship's flag State. ${ }^{\text {I59 }}$

In essence, the Court emphasized the necessary connection between the shipowner and the flag state. It concluded that 'UNCLOS does not establish rules intended to

\footnotetext{
I52 Case C-366/Io, Air Transport Association of America and Others v. Secretary of State for Energy and Climate Change, Judgment of the Grand Chamber of 2 I December 20I I, [20I I] ECR-I, n.y.r.; see on this case the critical analysis by A. Gattini, 'Between Splendid Isolation and Tentative Imperialism: The EU's Extension of Its Emission Trading Scheme to International Aviation and the ECJ's Judgment in the ATA Case', (2012) 6I ICLQ 977.

I53 Case C-366/Io, para. 49.

I54 See, for instance, Case C-344/04, The Queen on the Application of International Air Transport Association and Others v. Department for Transport, [2006] ECR I-403, para. 40.

I55 Kuijper, supra note I42, at 260.

I56 I 982 United Nations Conventions on the Law of the Sea, I833 UNTS 3.

I57 Case C-308/06, The Queen on the Application of International Association of Independent Tanker Owners (Intertanko) and Others v. Secretary of State for Transport, [2008] ECR I-4057, para. 54.

I58 Ibid., para. 58.

I59 Ibid., para. 59.
} 
apply directly and immediately to individuals and to confer upon them rights or freedoms capable of being relied upon against States' ${ }^{160}$ It has been noted that the breadth of the regulations set forth by UNCLOS is considerable and in other contexts some of its provisions have been held to be self-executing. ${ }^{16 \mathrm{I}}$ What is questionable, in any case, is the generalizing approach the Court took with respect to UNCLOS. In light of the Court's findings, it may be wondered whether the 'nature and broad logic' test is a suitable translation of the Vienna rules into a specific European approach to determining the direct effect of international agreements. While it appears as if this test can be used in a way which does not lead to conflicts with the generally recognized rules of interpretation, it seems as if it may also be used as a flexible tool to close the EU legal order against unwanted international influences. This suspicion finds some confirmation in the already mentioned ATAA case of 20 II. There, the ECJ was willing to attribute direct effect to a number of provisions of the 2007 Open Skies Agreement between the EU and the United States - but only for those provisions 'which would not be determinative to the outcome of the case'. ${ }^{\text {6 }} 2$

The case law that we have canvassed gives rise to a mixed picture. The ECJ is generally willing to apply the international rules of interpretation and has referred to them in parts of its jurisprudence. The Brita case has consolidated the ECJ approach in this respect as the Court has explained why it is having recourse to these rules. At the same time, the application of the principle of systemic integration in the Brita case appears to be a bit haphazard. In Intertanko, the sweeping discussion of the 'nature and broad logic' of UNCLOS raises doubts about the Court's willingness to make use of the international rules of interpretation when determining the direct effect of international agreements in the EU legal order.

\section{THREE JURISDICTIONS AND FOUR RECURRENT THEMES OF TREATY INTERPRETATION}

It is now time to turn to the four recurrent themes which we identified in our introduction. In the following, we will first revisit the case law of each of the three jurisdictions and discuss (i) whether it shows an awareness of the existence of a distinct hermeneutical framework for the interpretation of international law, (ii) whether the respective jurisprudence is likely to contribute to further fragmentation of the international legal system, (iii) whether the claim can be made that the particular approach of interpretation followed by the respective court shows traits of judicial imperialism, and (iv) whether the respective case law may give credence to Scelle's idea of the dédoublement fonctionnel. Subsequently, we will then engage in a comparison between the attitudes of the three courts.

\footnotetext{
I6o Ibid., para. 64

I6I See M. Mendez, 'The Legal Effects of Community Agreements: Maximalist Treaty Enforcement and Judicial Avoidance Techniques', (2010) 2I EJIL 83, at Ioo. This was also the result arrived at by Advocate General Kokott; see C-308/06, The Queen on the Application of International Association of Independent Tanker Owners (Intertanko) and Others v. Secretary of State for Transport, [2008] ECR I-4057, opinion of Advocate General Kokott, delivered on 20 November 2007, paras. 46-59.

I62 Gattini, supra note I52, at 986.
} 


\section{I. The US Supreme Court}

With respect to the US Supreme Court's treaty jurisprudence, the most salient feature is its dependency on the larger cultural-political trends prevalent in American society at the respective time. This is not to say that the Court conceived its methodology strategically in order to foster US foreign-policy goals. Rather, it demonstrates that treaty jurisprudence is but a part of the larger realm of law, which is itself a superstructure of society; in the famous words of Oliver W. Holmes, 'the prevalent moral and political theories, intuitions of public policy, avowed or unconscious, even the prejudices that judges share with their fellow-men, have a good deal more to do than the syllogism in determining the rules by which men should be governed'. ${ }^{163}$ That said, Georges Scelle's idealistic conception of the dédoublement fonctionelle has to be viewed with a certain reservation, at least as the US Supreme Court is concerned. History demonstrates that courts are rarely able to sever the invisible ties that bind them to their community and to fully assume the role of an organ of a different legal order. This is even observable in judges in genuinely international courts, and it must be much more so when domestic judges apply international law. However, this has also a positive side that appears as well in our study of US case law: at times when enthusiasm or at least a positive attitude towards international co-operation dominates public opinion, lasting achievements can be made, as long-standing precedents like the Charming Betsy decision demonstrate; thus, the ups and downs of public attitude towards international law that are inevitable in a democratic society can be moderated to some extent.

Concerning the risk of a further fragmentation of international law, the picture with respect to the US is mixed: at times, the Supreme Court went to great lengths to bring its interpretation of a treaty provision in accord with that of other domestic courts, as in Abbott v. Abbott. At others, it rather ignored the jurisprudence of the courts of other signatories, or even dismissed it as irrelevant - such as in Haitian Centers. In any event, it seems that if indeed the time for a greater openness has arrived again, it is not to be expected to take place through strict adherence to a set of international rules of interpretation, but through a general awareness of the specific nature of international agreements, and an increased respect for the jurisprudence of the courts of other parties. It has been noted above that the US Supreme Court hardly ever relied explicitly on the Vienna rules, and surely it repeatedly deviated from their constraints. Arguably this negligence not only is due to the fact that the US is not a party to the Vienna Convention, but also reflects the deeper indifference of a common-law judiciary to the project of creating a single authoritative international methodology. Nevertheless, it should be noted that the court frequently relied on a treaty's purpose in deciding which among different possible interpretations should be followed, a method prominently - and controversially - applied in the Abbott case. 


\subsection{The Mexican Supreme Court}

Our discussion of the development of treaty interpretation by Mexican courts confirms the finding from the US example that also questions of method and interpretative approach are largely dependent on political and social conditions. In Latin America, 'fragmented' political systems - as opposed to unitary systems built and functioning around an authoritarian executive - tend to set the conditions for the active development of the judiciary. ${ }^{164}$ It is therefore no surprise that Mexican judges and the Supreme Court in particular started to assume their proper role as a separate power once the democratization of the country began to materialize. This change of attitude is especially visible in contested cases of a certain political relevance where the importance of interpretation becomes more apparent. But beyond this and apart from strictly technical matters, international law tends to demand per se a new amount of autonomy from judges who were accustomed to regard the external sphere as the exclusive terrain of sovereigns embodied by their respective executives. This helps to explain why in matters of treaty interpretation the Mexican Supreme Court has moved from being a distant observer confined to formal requirements of treaty law, to embracing a more significant role concerned with the treaties' normative contents.

This puts international law in a different perspective for Mexico's top judges. Now that the Court finds itself called upon to clarify what 'the international commitments of Mexico' mean and to determine how they matter in and to Mexico, its function as agent of the state acquires a dimension which goes far beyond the aspect of avoiding triggering state responsibility. The Mexican Court is discovering that giving meaning to these commitments is a further means of augmenting its position within the national political system: treaty interpretation fulfils a judicial emancipatory function in Mexico's young democracy. This function is further strengthened if accompanied by transnational judicial actors. Becoming an 'agent of international law' is best understood in the present context as forming part of a transnational coalition of judges pursuing similar goals. ${ }^{165}$ The Inter-American human rights regime offers the natural frame to which Mexican judges can attach, and they are doing so, especially since the human rights reform of June 20II. Just as informal judicial coalitions have been acknowledged to perform an important function in relation to abuses of executive powers in several states in the framework of the international fight against terrorism, ${ }^{166}$ it is possible to regard the growing judicial dialogue in Latin America as a co-ordinated response to authoritarian reminiscences in an effort to maintain and strengthen judicial checks and balances domestically. Thus, although some do read the recent emphasis on the pro persona principle and the contrôle de conventionalité as an expression of the dédoublement fonctionnel

\footnotetext{
I64 Navia and Ríos Figueroa, supra note 8I, at I96.

I65 A tendency which is also reflected in the recent attention that the literature on transnational judicial cooperation has received by Mexican constitutionalists; see, e.g., S. M. Serna de la Garza, Impacto e Implicaciones Constitucionales de la Globalización en el Sistema Jurídico Mexicano (2012).

I66 See Benvenisti, supra note 2.
} 
thesis, whereby national judges would act as agents of the Inter-American system, ${ }^{\mathrm{I}}{ }_{7}$ this new interpretative approach by the Mexican Supreme Court, which does not follow the classical divide between the national and international legal orders, is too unidirectional to give account of the split of personality such a thesis presupposes, at least in Scelle's version.

There is nothing novel in national courts using international law for internal purposes, and if the (interpretative) means of doing this coincide with a broader, almost regional judicial attitude framed in the universal language of human rights law then one might think that Mexican courts and tribunals are indeed doing a service in favour of the unity of the international legal order. International human rights law is, no doubt, a key component of any effort to bring some constitutionality into international law. Enforcing human rights, here and there, does at the end fortify the common frame of reference. But the pro persona principle has the potential for inflation; every norm can be seen through the lenses of human rights under this method. Disregarding other applicable norms of international law, or engaging in such broad and loose interpretative exercises of treaty norms that hardly could reconnect to other judicial bodies not operating in the pro persona mood, certainly has a theoretical potential of furthering fragmentation at the international level. However, as already stated above, such judicial performances would rather fall into oblivion. Far more problematic is the effect they could have on human rights law itself. The risk of overstretching this regime is real, and a too extensive use of the pro persona principle may backfire.

It is in this regard that a more equilibrated recourse to questions of method could be useful for Mexican courts. For one reason or an other, Mexican judges do not tend to use the Vienna 'crucible', and have so far preferred to use the different ingredients of Article 3I (and Article 32) separately. A more nuanced hermeneutical approach would offer multiple paths to connect with the plurality of actors the Mexican Supreme Court has to address today, both internally and externally.

\subsection{The European Court of Justice}

Despite the different institutional position of the ECJ as the court of a regional system of integration, its approach to treaty interpretation is characterized by some similarities to the US and Mexican examples. The case law of the ECJ shows clearly that this court is aware of the existence of a distinct hermeneutical framework for treaty interpretation. This does not prevent the Court, however, from reasoning within this framework only in some cases in which questions of treaty interpretation are at stake. As we have seen, the most important exception in this sense is the Court's case law on the determination of direct effect of international agreements. Although there are indications in the Court's case law that the ECJ also understands this exercise as one of treaty interpretation, a special two-tier test is deployed which first analyses the nature and broad logic of the respective agreement before the Vienna rules on treaty interpretation intervene. While it is theoretically conceivable that

I67 See S. García Ramírez and M. I. Del Toro Huerta, México ante la Corte Interamericana de Derechos Humanos, Decisiones y Transformaciones (20I I), 2 I 8. 
this analysis of the nature and broad logic of an international agreement could be carried out following the Vienna rules, the practice of the ECJ does not follow these paths. Rather, as the Intertanko case shows, the court is more inclined to make generalizing conclusions about the nature of an international agreement which would be hard to arrive at if the Court followed the means of interpretation as set forth by Articles 3 I and 32 VCLT.

With this pick-and-choose attitude, the case law of the ECJ might also contribute to further fragmentation. As a powerful actor watched closely by other courts and tribunals, it could set a negative example for other courts. The Court, however, is not purporting to set forth a particular vision of treaty interpretation which it expects other domestic courts to follow. This at least could save the ECJ from charges of judicial imperialism. Rather, the ECJ's approach to treaty interpretation appears to follow the same logic which has been diagnosed in general with respect to this court's attitude to public international law: friendly and welcoming in general, but insisting on the autonomy of the EU legal system vis-à-vis traditional forms of international law when the really important issues are at stake.

The ECJ's case law pertaining to the interpretation of international treaties is clear, however, in so far as it shows the institutional loyalties of the Court. By not applying the Vienna rules precisely in the controversial domain of determining direct effect - arguably the most important task of treaty interpretation for the ECJ - it is implicitly showing that it has no institutional philosophy of dédoublement fonctionnel. On this point the ECJ is very clear: it is the guardian of a new legal order which is different from international law. It might be the precarious independence of EU law from international law which makes the case law of the ECJ so categoric in this regard.

\subsection{The recurrent themes compared: concluding remarks}

Analysing the above, we can identify both similarities and differences between the three jurisdictions. With respect to the awareness of the distinct international hermeneutical framework, the US Supreme Court is a special case in so far as its jurisprudence does not even try to engage with the Vienna rules of interpretation - certainly also due to the fact that the US is not party to the Vienna Convention, although the rules of interpretation are widely regarded as reflecting customary international law. In comparison, the case law of the Mexican and EU courts shows that they are generally well aware of the existence of the Vienna rules and are ready to apply them in at least some cases, though not always in a manner which is faithful to the underlying principles of these rules. Accordingly, the three case studies point to more diversity with respect to the approach of domestic courts towards the question of treaty interpretation than is usually acknowledged. ${ }^{\text {I68 }}$

Whether this plurality of approaches leads to further fragmentation remains an open question. The diversity of the practice of domestic courts certainly does not support the claim and aspiration for international law to provide a unitary set of 
secondary rules to which the rules of interpretation belong. The three case studies all point to the importance of political and social factors impacting on the case law of the courts, be it in the forms of varying degrees of openness towards the international in the US Supreme Court, the role of international law in the processes of emancipation from a previous authoritarian regime in Mexico, or the desire of the European Court of Justice to strengthen the autonomy of the EU legal order against traditional forms of international law. As applied by these domestic courts, the rules of interpretation do not retain a quality of perfectly neutral and objective rules which are immune from political power struggles. Rather, they are exposed to these struggles to the same extent as the substantive rules which need interpretation. This is not necessarily good news for the claim that the growing role of domestic courts is set to strengthen the international rule of law. It somewhat reduces the impact that judgments from domestic courts will have on the future development of international law. At least, the absence of consistent application of the Vienna rules of interpretation makes it more difficult for other courts and tribunals - be they international or domestic - to find inspiration in the domestic case law we have analysed.

Our three case studies give rise to doubts about the argument that this growing role of domestic courts is evidence for a renewed practical relevance of Georges Scelle's notion of the dédoublement fonctionnel. International law might conceivably harbour a certain expectation in this regard, i.e. that it aspires to make use of domestic courts as a substitute for its own lack of a central enforcement machinery. ${ }^{169}$ But from the perspective of domestic courts, the institutional loyalties appear to be clear. The case studies we have examined show that the respective courts have their own agendas, inspired by the political and social conditions relevant for their domestic, and sometimes regional, audiences. Recourse to the Vienna rules of interpretation might have indicated a sense of loyalty towards the international legal order. The absence of such recourse, or the diverse and fragmented use of the international rules of interpretation, cautions against unrealistic assertions of domestic courts as organs of the international community.

Finally, however, all this need not be evidence of new forms of judicial imperialism. With respect to the use of the rules of treaty interpretation, the practices of the three courts do not betray aspirations to become role models for other courts to follow. A special case in this regard is the Mexican Supreme Court, which has recently developed the judicial policy of making the widest possible use of the pro persona principle. This judicial strategy is inspired by a broader regional tendency, but primarily geared toward domestic tribunals. Perhaps it would be too much to say that it represents a new form of domestic judicial imperialism, but it certainly carries the risk of alienating the domestic judicial system. The US Supreme Court, in comparison, does not aspire to set forth a particular role model with its canons of treaty construction. It just follows its own tradition and, maybe also because of its own scepticism towards judicial dialogue, does not appear to expect that other

I69 See further A. Tzanakopoulos, 'Domestic Courts in International Law: The International Judicial Function of National Courts', (20 I I) 34 Loyola L.A. International and Comparative Law Review I53. 
domestic courts will follow its own example. The ECJ, finally, may in this regard be too much of a special case. While its concern to safeguard the autonomy of its own legal order may be read as just another variant of traditional and wellknown debates about the relationships between the international and domestic legal systems, its institutional peculiarities may prevent other courts from directly following its approaches to treaty interpretation.

Domestic courts from other jurisdictions we have not examined in this article may be more faithful to the international rules of interpretation. For this contribution, however, we did not want to select the easy cases. Rather, it was our goal to unearth the diversity in the practice of domestic courts - a diversity which is all too quickly negated in the interests of letting international law appear more integrated than it actually is. In the light of the case law we have analysed, uniformity in treaty interpretation is still far away-if achievable and desirable at all. However, this should not hinder domestic courts, when faced with questions of treaty interpretation, from pondering whether or not their jurisprudence should allow for a certain degree of systemic unity of the international legal system, which in turn facilitates judicial dialogue and cross-fertilization of their respective approaches. The Vienna rules of interpretation would be a valuable device in this regard - not much more but nothing less. It is for domestic courts to decide whether - and, if so, how - to make use of them. 